\title{
FRESHWATER MOLLUSCS OF THE ZRMANJA AND KRUPA RIVERS (CROATIA) - THE ROLE OF THESE RIVERS AS A REFUGE OF THREATENED AND ENDEMIC SPECIES
}

\author{
LUBOŠ BERAN
}

\begin{abstract}
Nature Conservation Agency of the Czech Republic, Regional Office Kokořínsko - Máchův kraj Protected Landscape Area Administration, Česká 149, CZ-276 01, Mělník, Czech Republic (e-mail: lubos.beran@nature.cz); (1) https://orcid.org/0000-0002-5851-6048
\end{abstract}

\begin{abstract}
The Balkan region is inhabited by hundreds of endemic species of freshwater molluscs but the information on their distribution, as well as that on the distribution of more common and widespread species, is still insufficient; most areas have no complete inventories of their mollusc faunas. The Zrmanja is one of the largest rivers in the Adriatic part of Croatia. Its freshwater molluscs were studied in the last decade, resulting in a substantial body of distributional data. The main objective of this study was to summarise and analyse the recent distributional information on its freshwater molluscs, with special reference to endemic or threatened species. In total 33 freshwater mollusc species were found in the Zrmanja River and its tributaries at 73 sites. The middle section of the Zrmanja River and its largest tributary, the Krupa River, were the richest studied parts. Dalmatinella fluviatilis Radoman, Tanousia zrmanjae (Brusina) and Islamia zermanica Radoman, endemic to the Zrmanja catchment area, were found in the middle and lower sections of the river. Their occurrence is scattered and limited in area; T. zrmanjae is probably on the verge of extinction. The occurrence of the endemic Belgrandiella kusceri (Wagner), Hadziella sketi Bole and Kerkia sp. in springs or underground waters and an abundant population of Unio elongatulus C. Pfeiffer in the Zrmanja and Krupa Rivers is also noteworthy. The area can be regarded as an important part of the Balkan region, one of world's hotspots of global biodiversity. Although it is protected, there are still anthropogenic factors that are negatively affecting or may affect the mollusc assemblages.
\end{abstract}

KEY WORDS: Mollusca; hotspot; endemics; threatened species; Zrmanja

\section{INTRODUCTION}

The Balkan region holds a rich freshwater fauna and belongs among the world's hotspots of global biodiversity (GRIFFITH et al. 2004). Dalmatia is regarded as a global hotspot of hydrobiids (MILLER et al. 2018). Many mollusc species (mostly gastropods) in the region have small, restricted ranges and are only found in small hydrographic systems: rivers, lakes or springs (RÉGNIER et al. 2009). Most rivers arising and flowing within the Mediterranean watershed typically drain small catchments (THORNES et al. 2009). This is also the case of the Zrmanja River which is one of the largest rivers in the Adriatic part of Croatia, despite its length of only $69 \mathrm{~km}$ and the catchment area of $907 \mathrm{~km}^{2}$.

The Zrmanja River is ranked as one of the European or global hotspots of freshwater gastropod diversity (STRONG et al. 2008, BERAN et al. 2015). Tanousia zrmanjae (Brusina, 1866), Hadziella sketi Bole, 1961, Belgrandiella krupensis Radoman, 1973, B. zermanica Radoman, 1973, Dalmatinella fluviatilis Radoman, 1973 and Islamia zermanica Radoman, 1973 were described from the Zrmanja River and 
its catchment area. Research focusing on freshwater gastropods was done in this area in the last decade (e.g. BERAN 2011, 2017, FALNIOWSKI \& SZAROWSKA 2013, FALNIOWSKI \& BERAN 2015, BERAN et al. 2015, 2016).

The research yielded a considerable set of distributional data. The main objective of this study was to summarise and analyse the recent distributional information on freshwater molluscs with special reference to endemic or threatened species, their status and preferable habitats, and to provide an assessment of the current situation of freshwater molluscs and support for the conservation of the Zrmanja and Krupa rivers catchment area.

\section{MATERIAL AND METHODS}

\section{STUDY AREA}

The Zrmanja is a river (Figs 1-5) in southern Lika and northern Dalmatia (Croatia). It is $69 \mathrm{~km}$ long and its basin is $907 \mathrm{~km}^{2}$ in area. The source of the Zrmanja River is located in the southern part of Lika below Postak, the southern peak of the Pljesevica Mt., and close to the southern end of the Velebit Mts. It flows southward through the narrow and long arable valley which encircles the southern end of the Velebit through a deep canyon, then turns westwards to reach Obrovac, and after a few kilometers flows into the Adriatic Sea in the bay of Novigradsko more (BERAN 2011). Its most important tributary is the Krupa River. The waters of two sinking rivers, Ričica and Žižinka, which flow through the north-eastern

part of the Gračac Plateau, reappear in many karst springs located on the right bank of the Zrmanja and Krupa rivers (BONACCI \& ROJA-BONACCI 2015a, b). The Krupa River and the Zrmanja River downstream of the inflow of the Krupa River differ in character from the upper section of the Zrmanja River. The upper course of the Zrmanja River has a torrential character and is almost devoid of travertine cascades and waterfalls (Fig. 5). This section occasionally dries up. The Krupa River (Figs 1, 6), as well as the middle (Figs 3, 4) and the lower (Fig. 2) sections of the Zrmanja River hold numerous natural barriers (travertine cascades and waterfalls), resulting in alternation of shallow torrents with deeper, slow-flowing sections. The reversible hydroelectric power plant Velebit (RHEPP Velebit), which started operating in

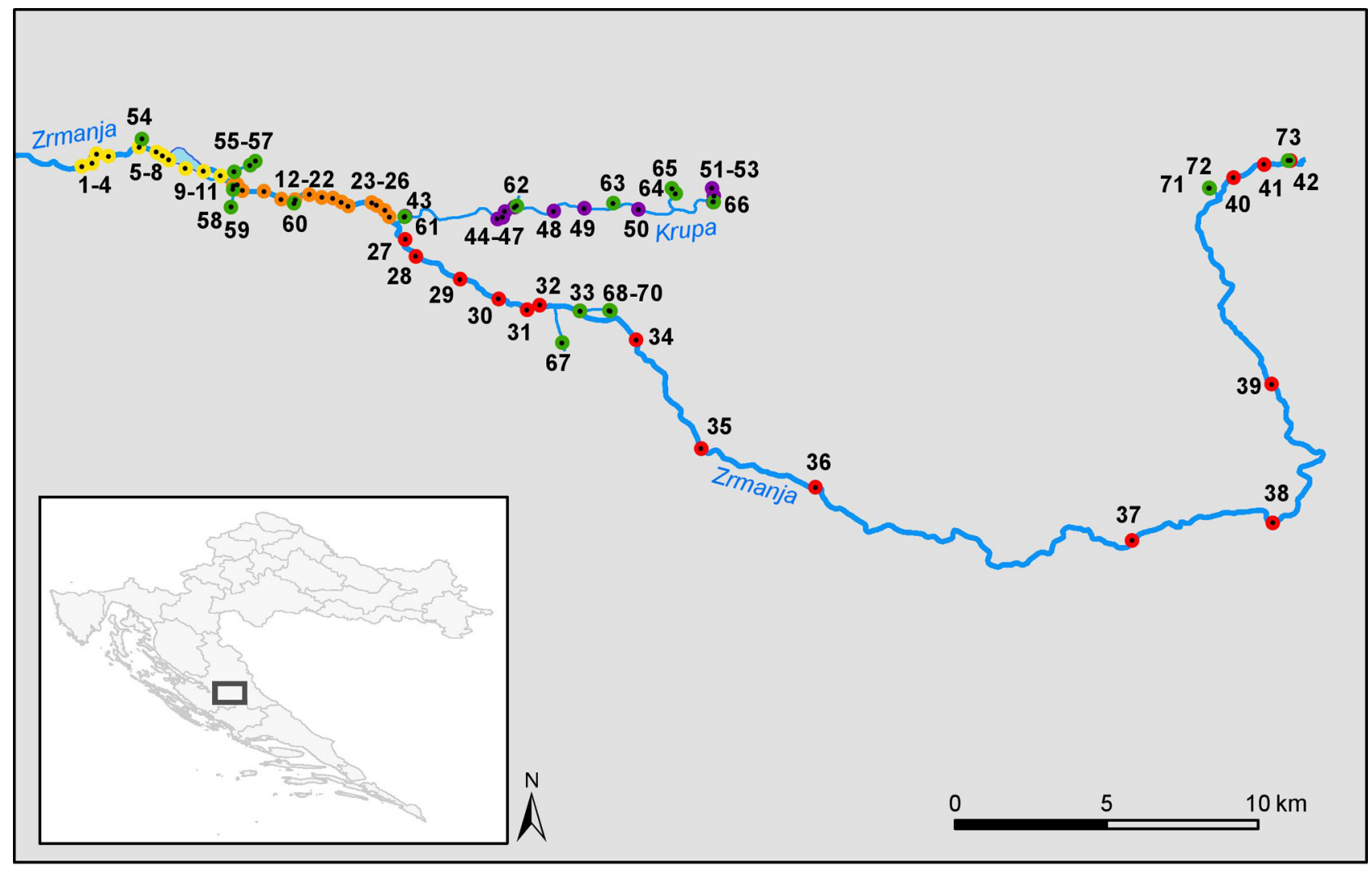

Fig. 1. Map of the Zrmanja River and its tributaries with the geographical distribution of the sampling sites. Yellow Zrmanja I, orange - Zrmanja II, red - Zrmanja III, purple - Krupa, green - small tributaries and springs. Drawing H. MEDKOVÁ 
1985, was built in the lower section of the Zrmanja River (BONACCI \& ROJA-BONACCI 2015b). It caused changes in the hydrological regime (BONACCI \& ROJA-BONACCI 2015b) and flooded a ca. $1.5 \mathrm{~km}$ long section of the river with two waterfalls.

During the Pleistocene, the Zrmanja River flowed southward, and fell into the Krka River. However, ca. 40,000 years ago it changed its course to what it is today. Its present bed is only a remain of the watercourse of the last Ice Age when the sea level was about $135 \mathrm{~m}$ lower than it is today. At that time the Zrmanja River flowed through the present area of the Novigrad Sea and continued farther through the Velebit channel between the islands of Pag and Rab, and then south near the islands of Cres, Lošinj and Premula to the confluence with the palaeo Po River.

The Zrmanja River and its tributaries are situated in the Velebit Nature Park. The Zrmanja River and the springs in Muškovci are the source of drinking water for Zadar.

\section{SAMPLING AND MATERIAL PROCESSING}

I collected the data in 2009-2020. The freshwater part of the Zrmanja River, the Krupa River, their small tributaries and the springs in their catchment area were studied at 73 sites (Fig. 1, Appendix 1). The freshwater part of the Zrmanja River was divided in three sections: Zrmanja I (loc. 1-11, Fig. 2) the lower section of the river including the Razovac dam reservoir, Zrmanja II (loc. 12-26, Figs 3, 4) - the middle section between the Razovac dam reservoir and the inflow of the Krupa River, and Zrmanja III (loc. 27-42, Fig. 5) - the upper section upstream of the inflow of the Krupa River. Altogether 11 sites (loc. 43-53, Figs 6, 7) were located on the Krupa River and 20 sites (loc. 54-73) were in different small tributaries and springs. The main sampling method used was washing vegetation and sediments using metal sieves (diameter $20 \mathrm{~cm}, 0.8 \mathrm{~mm}$ mesh and/ or diameter $10 \mathrm{~cm}, 0.5 \mathrm{~mm}$ mesh) combined with collecting by hand from the surface of stones, wood and artificial materials (e.g. plastic bags and bottles). Snorkelling in shallow parts (to ca. $3 \mathrm{~m}$ deep) was also used. The molluscs were identified based on their shell characters and, when necessary, on the structure of their copulatory organs. Specimens for dissection were killed in hot water and then fixed in $80 \%$ pure ethanol, while specimens for further DNA analysis were directly fixed in $80 \%$ pure ethanol. Selected shell material and specimens fixed in $80 \%$ ethanol are deposited in the author's collection.

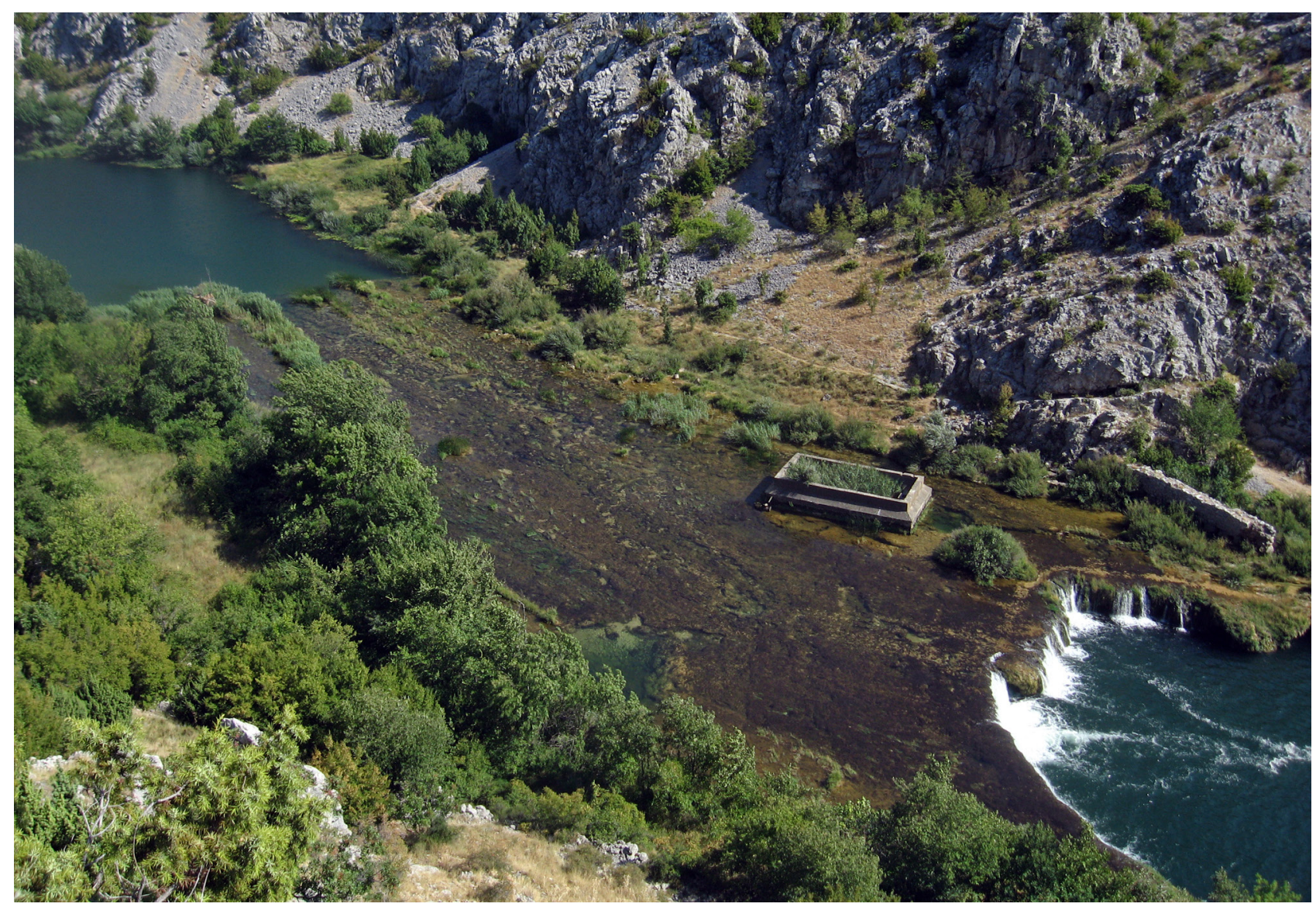

Fig. 2. Jankovića buk waterfall (loc. 1) is the border between the brackish and the freshwater sections of the Zrmanja River. Photo: LUBOŠ BERAN 


\section{RESULTS}

\section{MOLLUSC ASSEMBLAGES}

In total, 33 freshwater mollusc species were found in the rivers Zrmanja and Krupa with their tributaries and springs: 24 gastropods and 9 bivalves (Appendix 2: Tables 1-5). The Zrmanja River harbours 29 species. Only 17 species were recorded in the upper section of the Zrmanja River upstream of the inflow of the Krupa River (Zrmanja III, loc. 27-42), while downstream the assemblages included 25 (Zrmanja II, loc. 12-26) and 22 (Zrmanja I, loc. 1-11) species (Fig. 8, Appendix 2: Tables 1-3). Twenty six species were recorded in the Krupa River (loc. 43-53) and the same number was found in the various small tributaries and springs in the environs of these two rivers (Fig. 8, Appendix 2: Tables 4-5). The middle section of the Zrmanja and the Krupa Rivers were the richest in molluscs. Theodoxus fluviatilis, Sadleriana fluminensis, Bithynia tentaculata, Valvata piscinalis, Stagnicola fuscus, Radix ampla, Planorbis carinatus, Unio elongatulus, Pisidium amnicum and P. subtruncatum were most frequent in these sections. The assemblages of the upper section of the Zrmanja River were significantly poorer and also different from those inhabiting the remaining sections and the Krupa River. Radix labiata and Planorbis planorbis occurred only in the upper section, instead of $R$. ampla and P. carinatus which were found in the middle and lower sections of the Zrmanja and in the Krupa Rivers. Pyrgula annulata, Dalmatinella fluviatilis, Radomaniola curta, Tanousia zrmanjae, V. piscinalis, Acroloxus lacustris, Hippeutis complanatus, as well as U. elongatulus and Anodonta exulcerata were not recorded in the upper section, while $B$. tentaculata, Emmericia patula and S. fuscus were found in only one or two lowest-situated localities of the upper section. Gyraulus parvus was the only species with the occurrence limited to the upper section of the Zrmanja River. Sphaerium corneum was found only in the Krupa River and its tributary the Krnjeza Brook. A total of 26 species were found in the various small tributaries and springs. Islamia zermanica occurred in only one spring (loc. 59). A list of the studied sites and the species found at particular localities are shown in Fig. 1 and in Appendices 1 and 2 (Appendix 2: Tables 1-5).

\section{ZOOGEOGRAPHICAL REMARKS}

A third of the recorded species (11 species) have Cosmopolitan, Holarctic or Palaearctic distribution ranges (Fig. 8). Nearly as many (9 species) are distributed in Euro-Siberia or Europe. Most (12) of the recorded species are narrowly distributed. According to current knowledge, $P$. annulata, S. fluminensis, E. patula, U. elongatulus and A. exulcerata occur predominantly in the Adriatic Sea basin while the distribu-

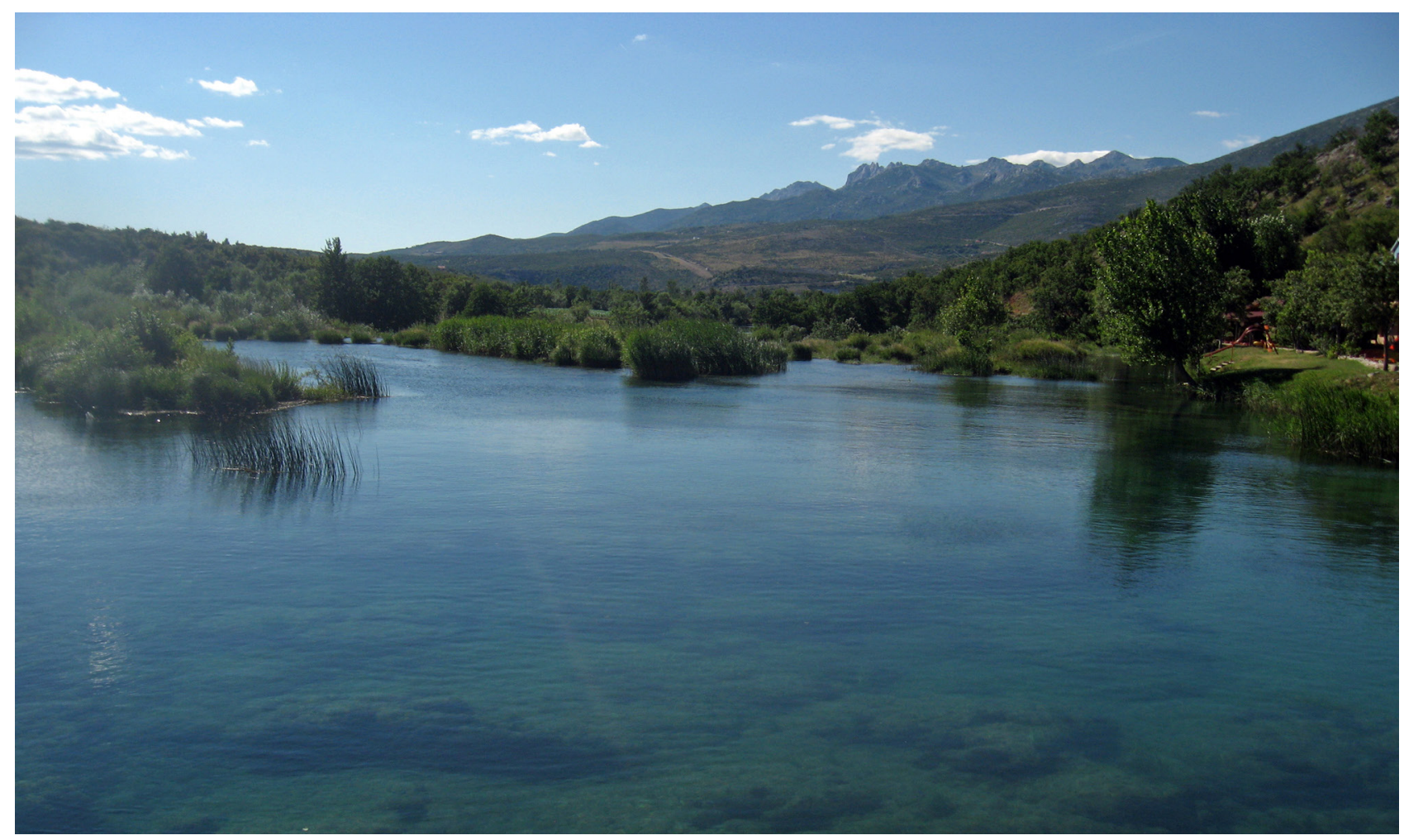

Fig. 3. The Zrmanja River upstream of the Berberov buk waterfall (loc. 13) inhabited by the population of Dalmatinella fluviatilis. Photo: LUBOŠ BERAN 
tion of Belgrandiella kusceri, H. sketi, Kerkia sp. and $R$. curta is limited to different-sized parts of Croatia with an overlap with the adjacent countries in the case of some species. However, the taxonomic status of some of the above-mentioned taxa is still uncertain and it cannot be ruled out that further studies using molecular genetic methods may reveal new endemic species. D. fluviatilis, T. zrmanjae and I. zermanica are endemic to the Zrmanja River catchment area. Corbicula fluminea (O. F. Müller, 1774) is an invasive non-native species, originally from Asia.

The upper section of the Zrmanja River (Zrmanja III) has the smallest proportion of narrowly distributed species (Fig. 8) while the middle section (Zrmanja II) has the largest proportion of such species. Species endemic to the Zrmanja River catchment area inhabit only its lower and middle sections and one isolated spring (see below).

\section{ENDEMIC, THREATENED AND RARE MOLLUSCS}

Most of the recorded species are common, listed in the current version of the IUCN Red List (IUCN 2020) under the category Least Concern. Only a few are listed as Critically Endangered (T. zrmanjae, I. ze- rmanica), Endangered (D. fluviatilis) and Vulnerable (H. sketi). The remaining species (B. kusceri, Kerkia sp., U. elongatulus, A. exulcerata) are listed under Data Deficient or not listed due to their recently revised or uncertain taxonomic status. For notes on their distribution, habitats and taxonomic status see below. Their distribution in the studied area is shown in Figs 9 and 10.

\section{Tanousia zrmanjae}

It is probably the last surviving species of the genus (BERAN et al. 2015). Only two populations were found during the recent survey, at loc. 18 and 19 (BERAN 2017). The population at loc. 18 (Fig. 4) was found only in 2012, 2013 and 2014; no live snails were observed in 2016 and 2019 (BERAN 2017 and this study). Empty shells (Fig. 11) were found only in the freshwater section of the Zrmanja River, between the Jankovića buk waterfalls and the inflow of the Krupa River. Neither live specimens nor shells were recorded in the Krupa River or in the Zrmanja River upstream of the Krupa inflow (BERAN 2017 and this study). Live specimens were recorded at the depths of 0.2 to $4.5 \mathrm{~m}$ within a discontinious area of a few square metres (BERAN 2017).

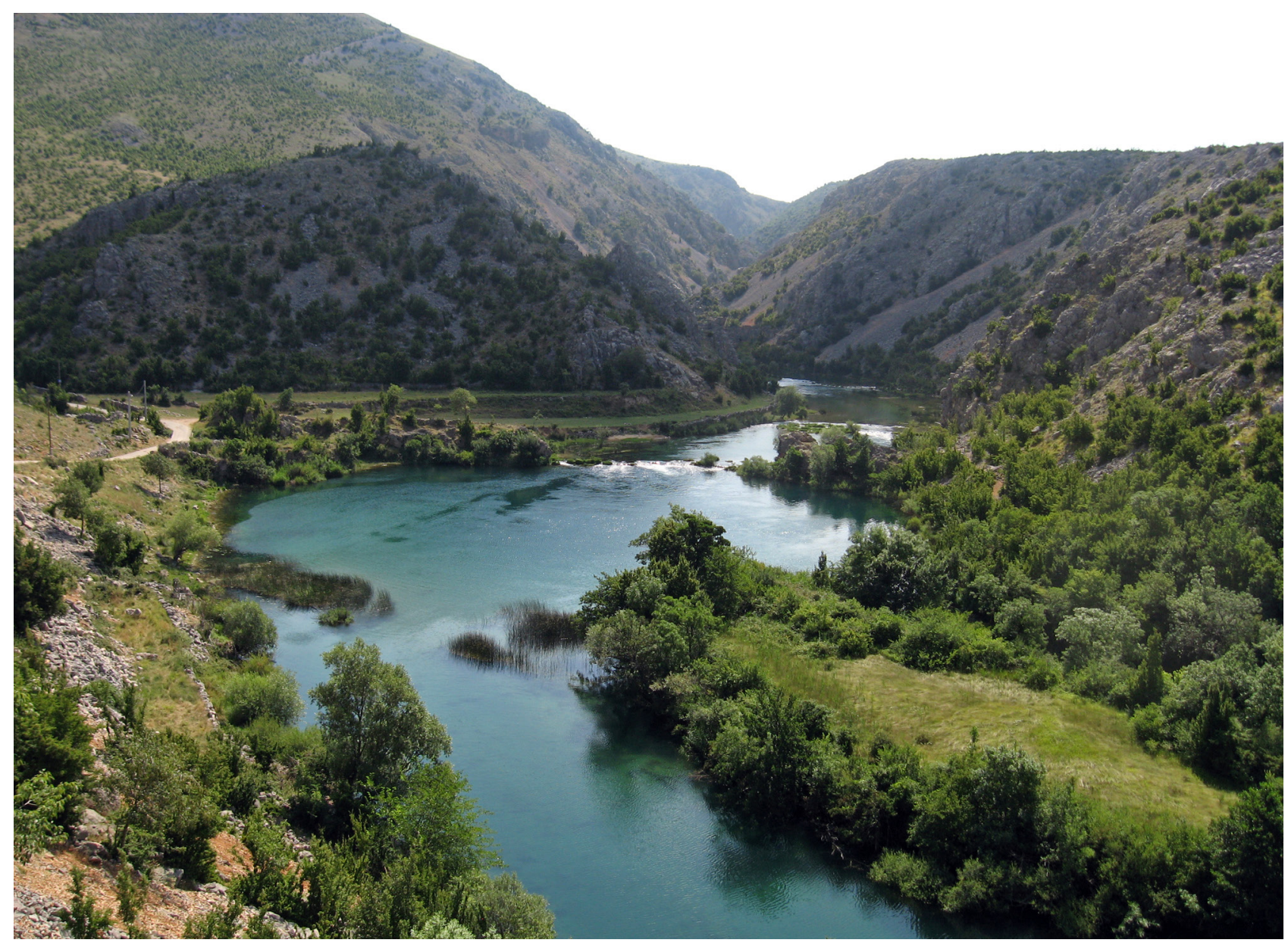

Fig. 4. The Zrmanja River in its middle section (loc. 18). Photo: Luboš BerAN 


\section{Dalmatinella fluviatilis}

D. fluviatilis was described from the middle part of the Zrmanja River in 1973 (RADOMAN 1973). The species was also mentioned from the lowest section of the Neretva River between Kula and Opuzen (RADOMAN 1983). Considering the distance between the Zrmanja and the Neretva Rivers, exceeding 200 $\mathrm{km}$, without any records inbetween, FALNIOWSKI \& SZAROWSKA (2013) expressed doubts if the same species of Dalmatinella could be present at both localities. Current research confirmed this assumption and a new species, D. simonae Beran et Rysiewska, 2021, found in the Cetina and Neretva Rivers including Bačina lakes, was described (BERAN et al. 2021, own unpublished results). BERAN (2011) found only a few specimens on stones at loc. 8 (loc. 19 in this study). FALNIOWSKI \& SZAROWSKA (2013) found this species at the Jankovića buk waterfalls (loc. 1 in this study). I found several specimens also at loc. 1. More abundant and more continuous occurrence was found at a less than $300 \mathrm{~m}$ long section of the Zrmanja River (loc. 13 and 14, Fig. 3). D. fluviatilis was found in shallow places on stones at loc. 1, 19 while at loc. 13 and 14 it occurred mostly on the vegetation at the depths ranging from 0.5 to $2 \mathrm{~m}$.

\section{Islamia zermanica}

Islamia is a genus of minute freshwater snails of the family Hydrobiidae. I. zermanica was described from the freshwater section of the Zrmanja River (RADOMAN 1973). The species was found by A. Falniowski and M. Szarowska at the Jankovića buk waterfalls (BERAN et al. 2016, loc. 1 in this study) and by myself in a small spring at Berberi (loc. 59). The species is regarded as endemic to the Zrmanja River catchment area (RADOMAN 1983, BERAN et al. 2016).

\section{Hadziella sketi}

H. sketi is a small gastropod living in karstic groundwaters and was described from a cave near Obrovac (BOLE 1961). Its description was based exclusively on shells and its distribution is not well known yet. BILANDZIJA \& JALZIC (2011) mentioned its occurrence from the Krka National Park. H. sketi was found in springs in the upper section of the Krupa River. Many old and fresh shells were found at loc. 53 and 65 while only old shells were recorded at loc. 51, 52, 64 .

\section{Kerkia sp.}

Kerkia is a genus of minute valvatiform gastropods living in karstic groundwaters. Fresh shells were found only in the source of the tributary of the Krupa River (loc. 65), while only old shells were collected at loc. 53, 54, 61. Due to the fact that only shells were found during this study the taxonomic status is uncertain because more species of the genus are known from this part of Croatia. $K$. kareli Beran, Bodon et Cianfanelli, 2014 was described from Pag

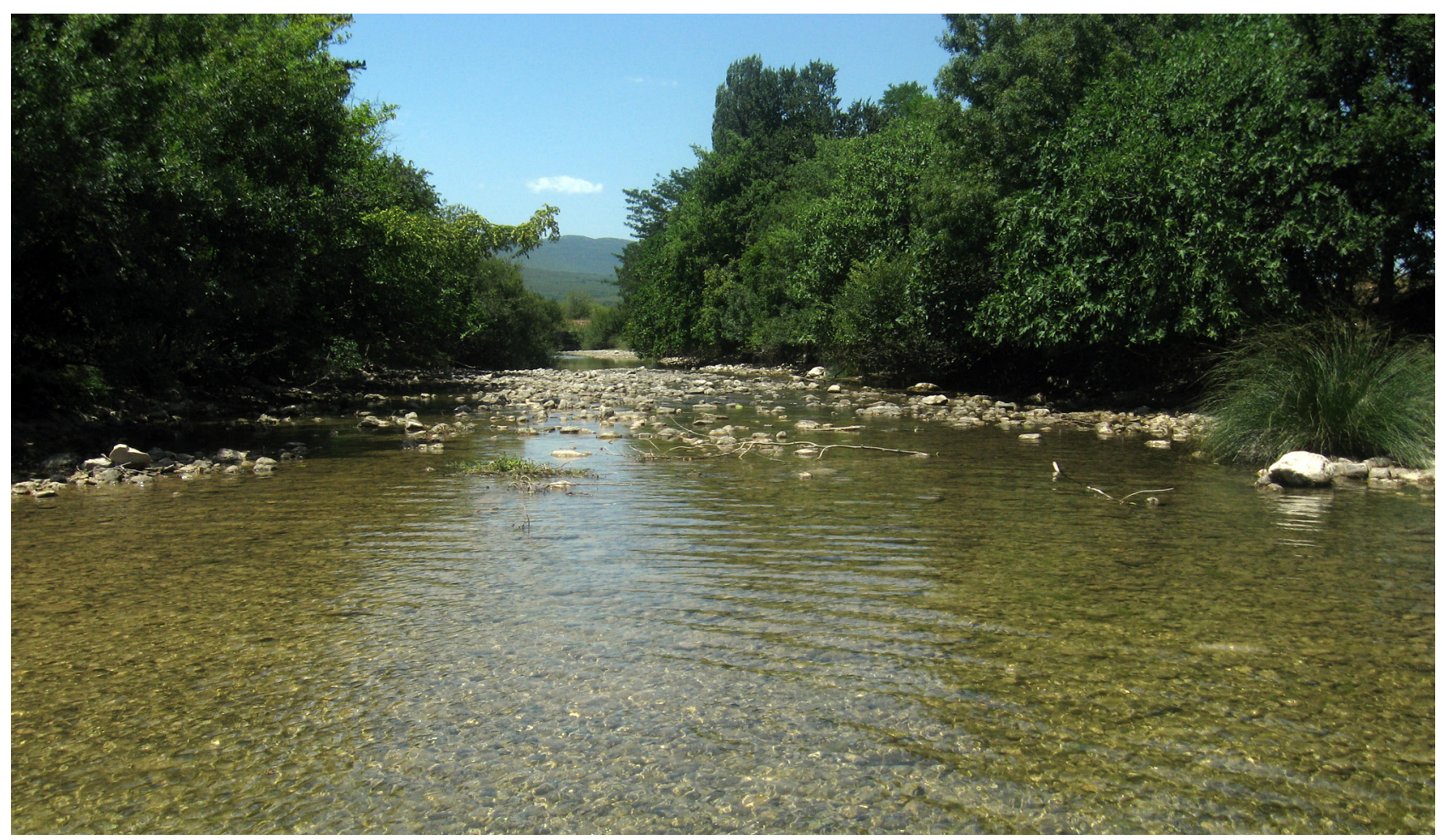

Fig. 5. The Zrmanja River in its upper section, of a torrential character nearly without travertine cascades and waterfalls (loc. 36). Photo: LUBOŠ BERAN 
Island (BERAN et al. 2014) while K. jadertina (Kuščer, 1933) is known from more sites in the Split region (BERAN et al. 2014). The nearest site with the occurrence of live specimens is Ljubač near Pag Island, ca. $50 \mathrm{~km}$ to the northwest. The population in Ljubač may represent a still undescribed species (RYSIEWSKA et al. 2017).

\section{Belgrandiella kusceri}

RADOMAN (1973) described two species of the genus Belgrandiella from the Zrmanja River catchment area: B. krupensis from the source of the Krupa River and B. zermanica from the Zrmanja River above the Jankovića buk waterfalls. However, it has to be noted that the distinctness of these species is doubtful and both should be synonymised with B. kusceri (FALNIOWSKI \& BERAN 2015, OSIKOWSKI et al. 2018). B. kusceri was found at loc. 19, 29, 41, 50-53, 56, 60, $66,70,71$. The shell morphology of the specimens from loc. 60 corresponds to $B$. zermanica while the remaining ones - to $B$. krupensis.

\section{Unio elongatulus}

The range of $U$. elongatulus extends from north of the Apennines in Italy to coastal Croatia (FroufE et al. 2017) and probably even further south (M. LOPES-LIMA, pers. comm.). The species has not been assessed by the IUCN since it has only recently been recognised and distinguished from $U$. mancus Lamarck, 1819 which is listed in the last version of the IUCN Red List as Near Threatened (LOPES-LIMA \& SEDDON 2014). It is among the most common species in the Zrmanja and Krupa rivers and was found at 33 of the studied sites (Fig. 10, Appendix 2: Tables $1-4)$. Very abundant populations of this bivalve were found in most of the studied sites in the lower and middle sections of the Zrmanja River (Zrmanja I, II), including the Razovac dam reservoir and the Krupa River. Due to the heterogeneous river bed the occurrence was irregular, but in suitable places the density exceeded several hundred individuals per square metre and in many sites the species constituted the dominant component of molluscan biomass together with the other dominant molluscs such as T. fluviatilis or B. tentaculata.

\section{Anodonta exulcerata}

A. exulcerata appears to be endemic to the region ranging from the Italian Peninsula to Croatia and to the west of the Dinaric Alps (FroufE et al. 2017). It has not been assessed by the IUCN since it has only recently been recognised as a distinct species; according to FROUFE et al. (2017) more research is needed for a precise assessment of its conservation

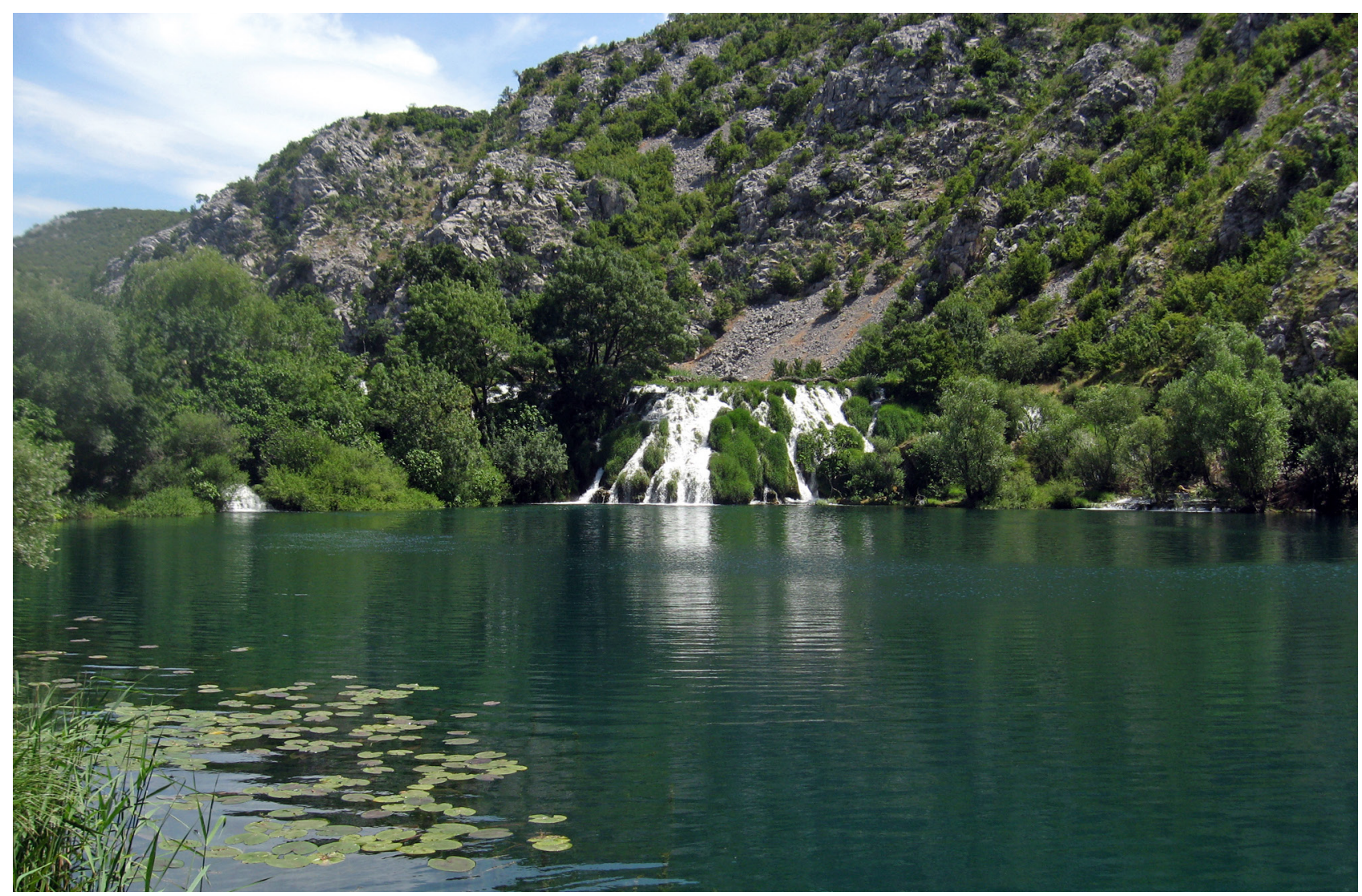

Fig. 6. Travertine cascades and waterfalls are frequent in the lower section of the Krupa River (loc. 44). Photo: LUBOŠ BERAN 
status. A scattered or rare occurrence was observed in the lower and middle sections of the Zrmanja River (Zrmanja I, II) including the Razovac dam reservoir, in the Krupa River and in the Dabarnica Brook (loc. 55) (Fig. 10, Tables 1-5). Usually only a few specimens per site were found compared to tens or hundreds (thousands) of individuals of $U$. elongatulus.

\section{NON-NATIVE SPECIES}

One non-native species was recored. C. fluminea was found at loc. 1 (Fig. 2) for the first time in 2019 and its occurrence was confirmed in 2020 (BERAN
2020). Only two young individuals (less than $10 \mathrm{~mm}$ ) were found in 2019, while a more abundant occurrence was documented in 2020. A scattered occurrence of live individuals was observed there, except the place where C. fluminea was found in 2019. In all, 42 specimens were found within an area of $1 \mathrm{~m}^{2}$ in the sediment at a shallow place $(50-70 \mathrm{~cm})$ near the river bank. Smaller specimens dominated (BERAN 2020). No empty shells were found during the 2019 and 2020 surveys. The same site was visited also in 2013 and 2015 and C. fluminea was not found there (BERAN 2020).

\section{DISCUSSION}

\section{MOLLUSC ASSEMBLAGES}

Rich mollusc assemblages inhabit the rivers Zrmanja and Krupa. They include both rheophilous species (e.g. T. fluviatilis, S. fluminea, E. patula, $R$. ampla, A. fluviatilis) and species preferring stagnant or slow-flowing waters (e.g. A. lacustris, S. fuscus, P. planorbis). The reason is the character of both riv-

ers, where slow-flowing parts are interspersed with waterfalls and fast-flowing sections. The assemblages of the middle and lower sections of the Zrmanja River are more similar to those of the Krupa River than the assemblages from the upper section of the Zrmanja River. These assemblages are poorer, with fewer endemic or threatened species. The occurrence of two pairs of related species is also notable. $R$. la-

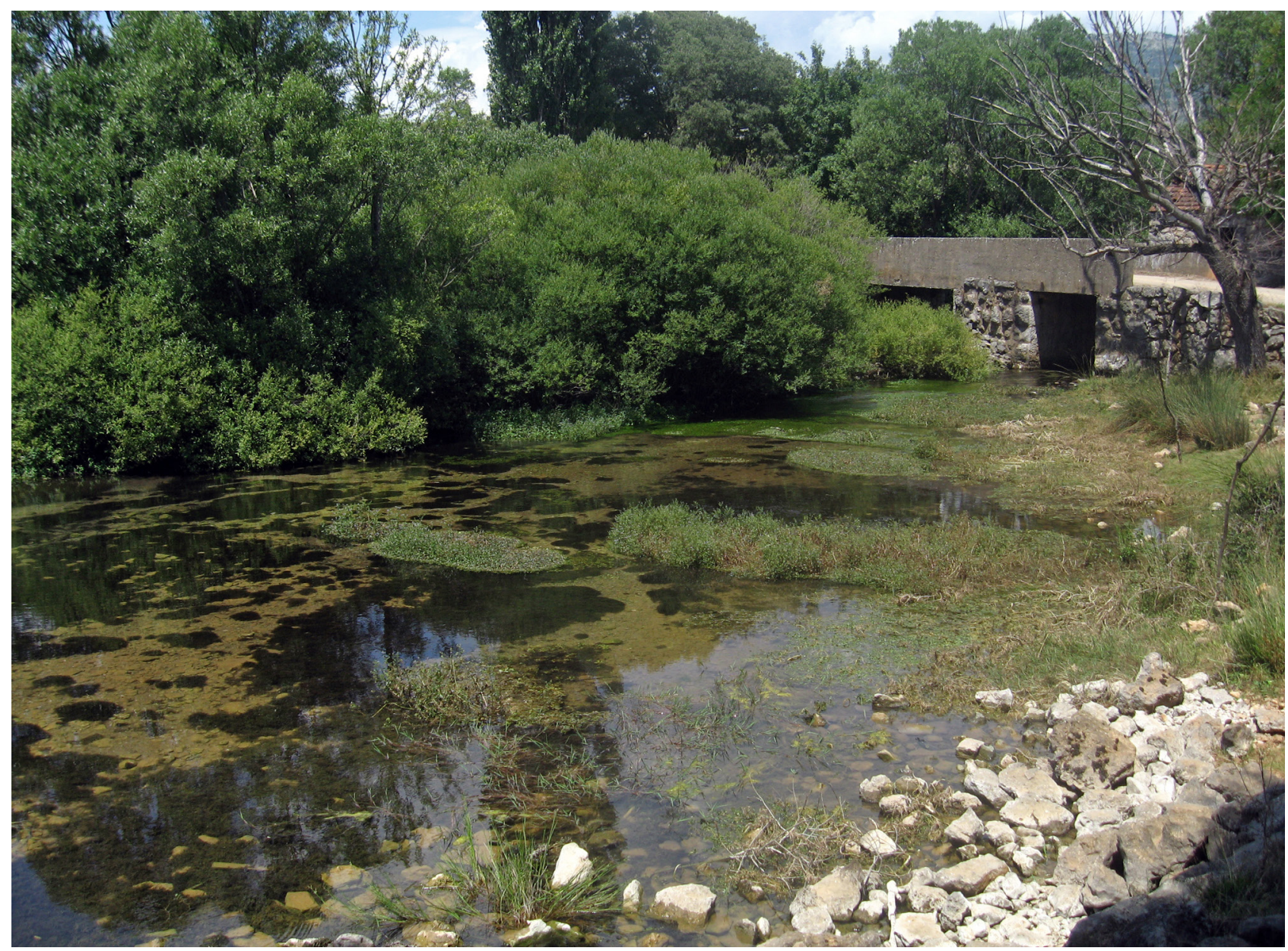

Fig. 7. The Krupa River in its upper section (loc. 51). Photo: LUBOš BERAN 


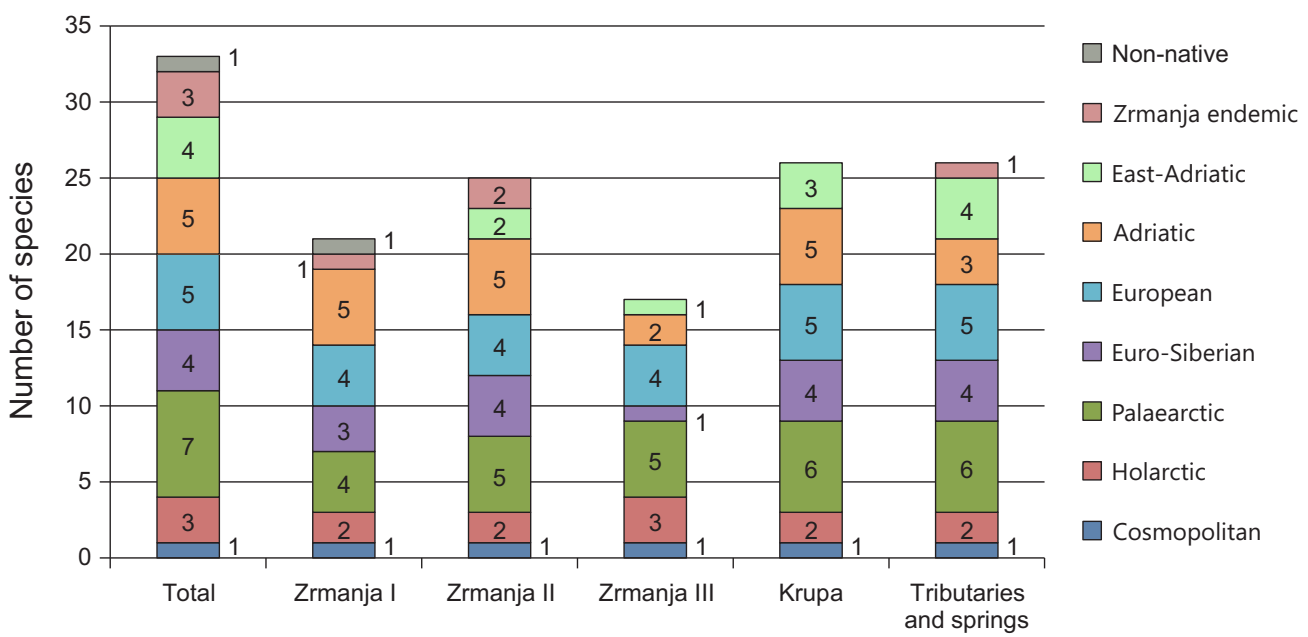

Fig. 8. Number of species recorded in particular sections and zoogeographical analysis of aquatic molluscs found in the Zrmanja River and its tributaries

biata and P. planorbis inhabit only the upper section of the Zrmanja upstream of the confluence of both rivers, while $R$. ampla and $P$. carinatus occur in the Krupa River and in the middle and lower sections of the Zrmanja River. The probable reason for this difference is the character of the upper section of the Zrmanja River. The upper course has a torrential character nearly devoid of travertine cascades and waterfalls (Fig. 5) and occasionally dries up, while natural barriers (travertine cascades and waterfalls), which cause the alternation of shallow torrents with deeper, slow-lowing sections exist in the Krupa River (Fig. 6) and in the middle (Figs 3, 4) and lower (Fig. 2) courses of the Zrmanja River.

The Krka River is the nearest bigger river in the Adriatic part of Croatia. During the Pleistocene, the Zrmanja River flowed southward, to join the Krka. The mollusc assemblages of the Krka River have been studied recently (VUČKOVIĆ 2013, BERAN 2016). Altogether 18, mostly common and widespread, freshwater species inhabit both rivers. The bivalve assemblages of the two rivers are very similar. Gastropods preferring slow-flowing waters, including A. vorticulus, an endangered species listed in the EU Habitats Directive, are more frequent in the Krka River. The probable reason is the existence of the extensive Visovac Lake and other lakes and pools created by travertine cascades. On the other hand, the Krka River (main current) is significantly poorer in small hydrobiids while small springs in the Krka catchment area harbour several endemic species, for example Lanzaia skradinensis Bole, 1992.

\section{HOTSPOT}

The Zrmanja River catchment area is regarded as one of the European or global hotspots of freshwater gastropod diversity (STRONG et al. 2008, FALNIOWSKI
\& BERAN 2015) but this statement probably does not correspond to reality and is rather due to the lack of data from other areas. Although several endemic species and also very rich mollusc assemblages occur there, there are other areas of similar character, with high diversity of endemic freshwater molluscs (mostly gastropods), especially in the Adriatic part of Croatia and adjacent countries (e.g. RADOMAN 1983) or in the whole Balkan region. This area, with its hundreds of endemic species of freshwater molluscs, mainly small hydrobiids, is thus a much more appropriate candidate for an important part of the Balkans, and is ranked as a hotspot of global biodiversity (GRIFFITH et al. 2004, STRONG et al. 2008) and also as the part of Dalmatia which is one of the most important hotspots of hydrobiid diversity (MilLER et al. 2018).

\section{THREATS, NOTES ON CONSERVATION STATUS OF THREATENED SPECIES}

Although the Zrmanja River and its tributaries are situated in the Velebit Nature Park, there are many anthropogenic factors that threaten its freshwater molluscs. The reversible hydroelectric power plant Velebit (RHEPP Velebit), operating since 1985, and located in the lower section of the river, has caused changes in the hydrological regime (BONACCI \& ROJA-BONACCI 2015b) and flooded a ca $1.5 \mathrm{~km}$ long section of the Zrmanja River with two waterfalls. Construction of another three new dams and hydro-power plants is planned in the middle and upper sections of the Zrmanja (BJEDOV 1995). The construction of new dams would significantly affect the river's mollusc assemblages and might lead to extinction of some species. Both rivers are located in a sparsely populated and little exploited area. However, especially in the environs of the Berberov 

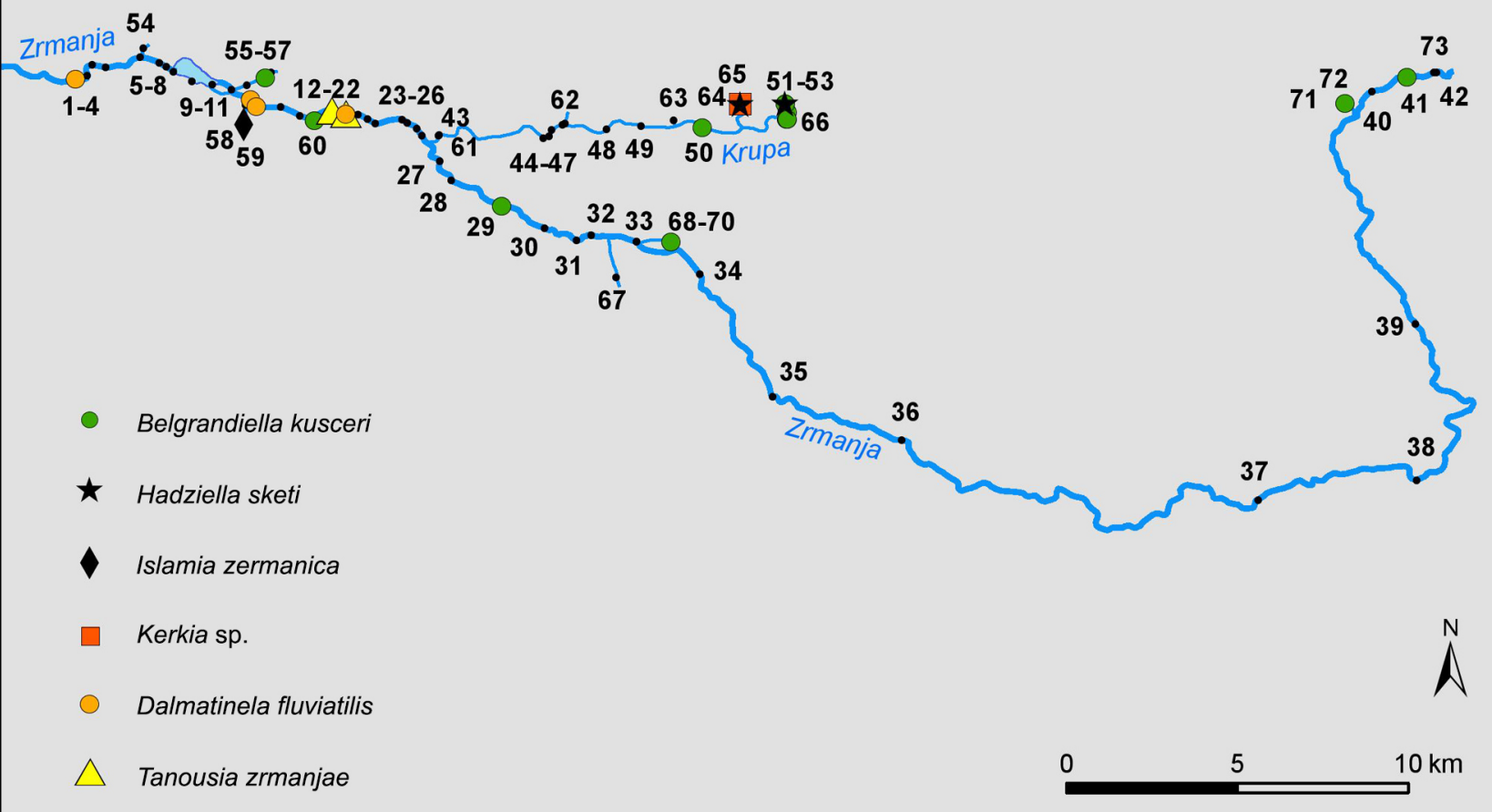

Fig. 9. Map showing the distribution of threatened and endemic gastropods. Drawing H. MEDKOVÁ
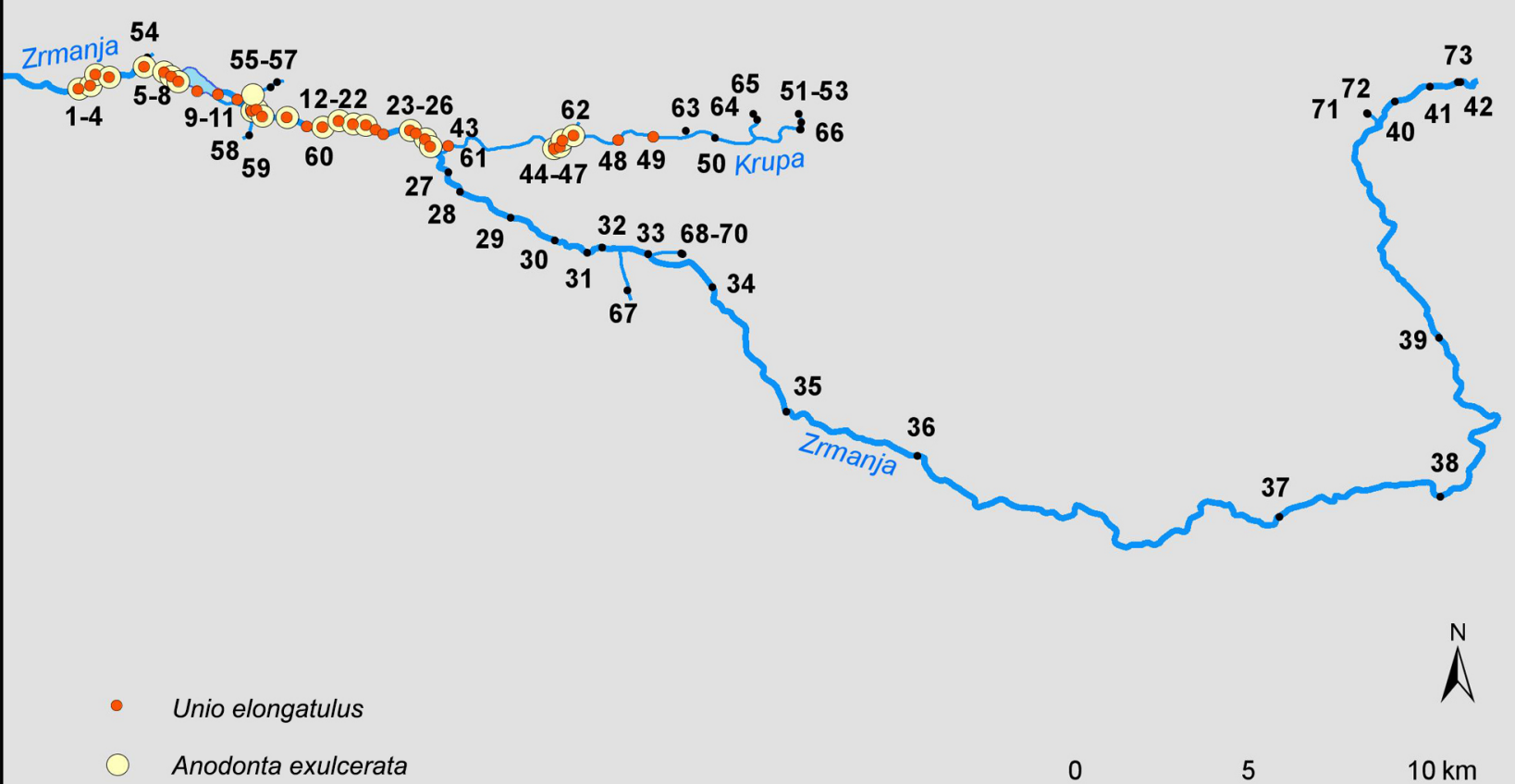

Anodonta exulcerata

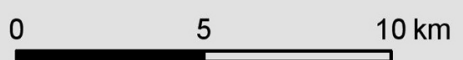

Fig. 10. Map showing the distribution of Unio elongatulus and Anodonta exulcerata. Drawing H. MEDKOvÁ 
buk waterfall, there is currently a development of recreational facilities (camps, restaurants). This trend may cause undesirable eutrophication of the Zrmanja River. In contrast, individual recreational activities (swimming, kayaking, rafting, sport fishing) probably have a minimal impact on the mollusc assemblages. Introduction or acceleration of invasion of non-native species (BERAN 2020) is an exception. The mollusc assemblages of the Zrmanja River are affected by one non-native species. C. fluminea was recorded for the first time in 2019 and its further expansion is expected (BERAN 2020). The invasion, together with high abundance, could have a negative effect, especially on bivalves. Invasion of other non-native species can be expected in the future. Physa acuta (Draparnaud, 1805 ) is common and widespread also in the Adriatic part of Croatia (ŽGANEC et al. 2020, BERAN unpublished records) and occurs for example in the Krka River catchment area (BERAN 2016). The Razovac dam reservoir is used for sport fishing; another non-native mollusc, Sinanodonta woodiana (Lea, 1834), can be introduced there with infected fish. Invasion of this species might have a negative effect on the autochthonous unionids (U. elongatulus, A. exulcerata).

The degree of threat is in some cases correlated with the distribution range. Three species endemic to the Zrmanja River catchment area are currently the most threatened molluscs. Only two area-limited sites with the occurrence of T. zrmanjae were found in the middle section of the Zrmanja River; a probable extinction or at least a significant decline in one of these two known sites was observed during the last ten years (BERAN 2017). The reasons for the decline are still unknown (BERAN 2017). Despite intensive searches, no live individuals were found anywhere else. T. zrmanjae should be regarded as critically endangered, with a high probability of extinction in the following years or decades (BERAN 2017). D. fluviatilis was found in the middle and lower sections of the Zrmanja. Only few individuals were found at loc. 1 and 19 in 2013 and 2010, respectively. Repeated searches of these sites in the following years were unsuccessful, but due to its small size the species is likely to have been overlooked and may be found there or at some new sites in the future. A more abundant population was found at a less than 300 $\mathrm{m}$ long section (loc. 13 and 14). D. fluviatilis can be regarded as endemic to the freshwater part of the Zrmanja River (see Results). Although the situation of this species is slightly better than in the case of T. zrmanjae, in view of the above facts it is desirable that in the further version of the IUCN Red List the species be reclassified from Endangered to Critically Endangered. At present, the distribution of the two species (T. zrmanjae, D. fluviatilis) is limited to a very short section of the Zrmanja River, whereas in the past their occurrence and also the occurrence of oth-

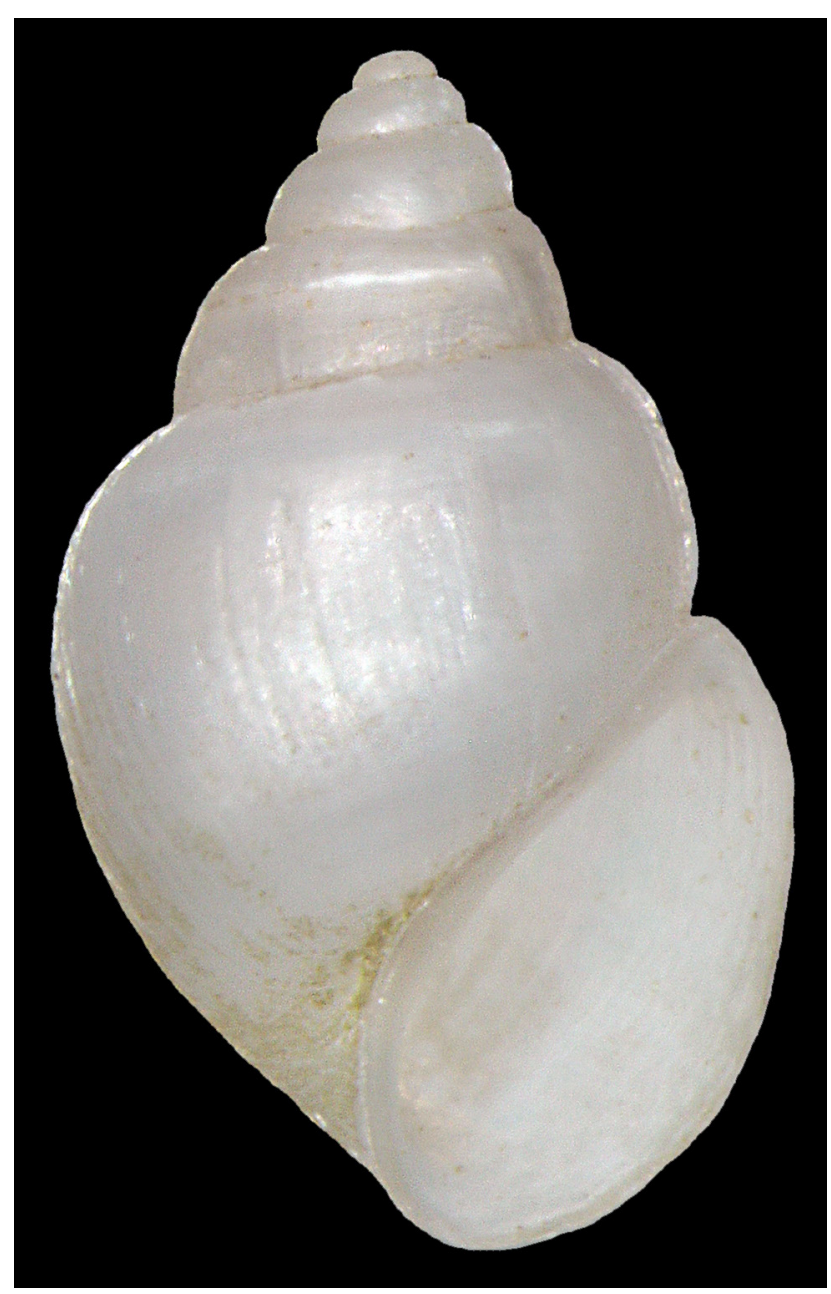

Fig. 11. Shell of Tanousia zrmanjae, the most threatened mollusc of the Zrmanja River. Photo: M. HORSÁK

er freshwater molluscs may have been much wider because in the last Ice Age the sea level was more than 135 m lower, the Zrmanja River was significantly longer and flowed into the palaeo Po River. This is supported by the fact that fossil shells of $T$. zrmanjae were also found in the brackish section of the Zrmanja River near Obrovac (SCHLICKUM \& SCHÜTT 1971). I. zermanica is also regarded as endemic to the Zrmanja River catchment area. It was found in the Zrmanja River (BERAN et al. 2016, loc. 1 in this study) and in an isolated spring (loc. 59). In spite of intensive searches during the survey, it was not found in other sites. Due to its small size it may have been overlooked and may be also found in some springs in this area. Nevertheless, its status remains unsatisfactory and I. zermanica should be treated as a critically endangered species facing the threat of extinction.

The situation of other spring-dwelling molluscs (e.g. B. krupensis) is somewhat better in comparison with the rivers. Most of the springs have not yet undergone any drastic modifications. The probable reason is that water from the rivers is used for irriga- 
tion or as a source of drinking water more than water from small springs. In contrast, in areas without major watercourses, springs are the only sources of water (drinking or for irrigation) and they have often been drastically modified, which has significantly affected or destroyed their malacofauna (RADOMAN 1983, SZAROWSKA 2006, own observations from the environs of Zadar).

In the case of groundwaters, the situation is not very well known. Due to the sparse population and low exploitation it is assumed that there are no sig- nificant negative changes. The groundwaters in the upper section of the Krupa River are an important habitat for $H$. sketi. The number of shells found indicates that there still occur numerous populations, while the findings of Kerkia sp. are rather rare. H. sketi is listed in the current version of the IUCN Red List as Vulnerable (BILANDZIJA \& JALZIC 2011). Because its distribution is not well known yet, it would be advisable to reclassify it in the category Data Deficient and it is not excluded that the species is more threatened than currently believed.

\section{CONCLUSIONS}

The rivers Zrmanja and Krupa are refuge for endemic species and also host very rich mollusc assemblages which include endangered and rare species. The most important is the middle section of the Zrmanja River with the endemic T. zrmanjae and the abundant population of $D$. fluviatilis. However, the situation of the first species is critical and it may become extinct within a few years or decades without the causes of its extinction being identified.

This area is thus a very important part of the Balkan region, which is inhabited by hundreds of endemic freshwater mollusc species, mainly small

hydrobiids. Although it is protected, there are still anthropogenic factors that are negatively affecting or may affect the mollusc assemblages. The potential construction of other dam reservoirs is among the most serious threats.

\section{ACKNOWLEDGEMENTS}

I would like to thank HELENA MEDKOVÁ for drawing the maps, MichAL HORSÁk for the photo of the shell of T. zrmanjae and the anonymous reviewers for their valuable comments.

\section{REFERENCES}

BERAN L. 2011. Non-marine molluscs (Mollusca: Gastropoda, Bivalvia) of the Zrmanja River and its tributaries (Croatia). Natura Croatica 20: 397-409.

BERAN L. 2016. A contribution to knowledge of freshwater molluscs (Mollusca) of the Krka River in the Krka National Park (Croatia). Natura Croatica 25: 295-304. https://doi.org/10.20302/NC.2016.25.25

BERAN L. 2017. Notes on the distribution and status of Tanousia zrmanjae (Brusina, 1866) (Gastropoda: Truncatelloidea: Hydrobiidae). Folia Malacologica 25: 109-115. https://doi.org/10.12657/folmal.025.006

BERAN L. 2020. First records of Sinanodonta woodiana (Lea, 1834) and Corbicula fluminea (O. F. Müller, 1774) from the Adriatic part of Croatia. Folia Malacologica 28: 259-302.

https://doi.org/10.12657/folmal.028.024

BerAN L., BODON M., CiAnfanelli S. 2014. Revision of "Hauffenia jadertina" Kusčer, 1933, and description of a new species from Pag Island, Croatia (Gastropoda: Hydrobiidae). Journal of Conchology 41: 585-601.

BERAN L., HOFMAN S., FALNIOWSKI A. 2015. Tanousia zrmanjae (Brusina, 1866) (Caenogastropoda: Truncatelloidea: Hydrobiidae) a living fossil. Folia Malacologica 23: 263-271.

https://doi.org/10.12657/folmal.023.022

BERAN L., OSIKOWSKI A., HOFMAN S., FALNIOWSKI A. 2016. Islamia zermanica (Radoman, 1973) (Caenogastropoda: Hydrobiidae) morphological and molecular distinctness. Folia Malacologica 24: 24-30.

https://doi.org/10.12657/folmal.024.004

BERAN L., RYSIEWSKA A., HOFMAN S., OSIKOWSKI A., FALNIOWSKI A. 2021. A new species of Dalmatinella Radoman, 1973 (Caenogastropoda: Hydrobiidae) from Croatia. Journal of Conchology 44: 1-10.

BJEDOV T. 1995. Višenamjensko iskorištavanje akumulacijskih jezera rijeke Zrmanje. Građevinar 47: 679-684.

BILANDZIJA H., JALZIC B. 2011. Hadziella sketi. The IUCN Red List of Threatened Species 2011: r.T15585A4855018. https://doi.org/10.2305/IUCN.UK.2011-2.RLTS. T155852A4855018.en

BOLE J. 1961. Nove hidrobide (Gastropoda) iz podzemeljskih voda zahodnega Balkana. Biološki Vestnik 9: 5969.

BONACCI O., ROJE-BONACCI T. 2015a. Analiza hidroloških promena duž toka reke Zrmanje. Vodoprivreda 47: 177-186.

BONACCI O., RoJE-BONACCI T. 2015b. Drastic hydrological changes caused by hydroelectrical development in karst: a case of the karst river Zrmanja (Croatia). Environmental Earth Sciences 74: 1-11. https://doi.org/10.1007/s12665-015-4688-9 
FALNIOWSKI A., BERAN L. 2015. Belgrandiella A. J. Wagner, 1928 (Caenogastropoda: Truncateloidea: Hydrobiidae): how many endemics? Folia Malacologica 23: 187-191. https://doi.org/10.12657/folmal.023.015

FALNIOWSKI A., SZAROWSKA M. 2013. Phylogenetic relationships of Dalmatinella fluviatilis Radoman, 1973 (Caenogastropoda: Rissooidea). Folia Malacologica 21: $1-7$. https://doi.org/10.12657/folmal.021.001

Froufe E., LOPES-LimA M., RicCARdi N., ZACCARA S., VANETTI I., LAJTNER J., TEIXEIRA A., VARANDAS S., PRIÉ V., ZIETRITZ A., SOUSA R., BOgAN A. E. 2017. Lifting the curtain on the freshwater mussel diversity of the Italian Peninsula and Croatian Adriatic coast. Biodiversity Conservation 26: 3255-3274. https://doi.org/10.1007/s10531-017-1403-z

GRIFFITH H. I., KRYŠTUFEK B., REED J.M. 2004. Balkan biodiversity: pattern and process in the European hotspot. Kluwer Academic Publishers, Dordrecht.

IUCN 2020. The IUCN Red List of Threatened Species. Version 2020-3. Available online at https://www.iucnredlist.org (accessed 11 December 2020).

LOPES-LIMA M., SEDDON M. B. 2014. Unio mancus. The IUCN Red List of Threatened Species 2014: e. T22737A42466471.

https://doi.org/10.2305/IUCN.UK.2014-3.RLTS. T22737A42466471.en

Miller J. P., Ramos M. A., HaUffe T., DeliCado D. 2018. Global species richness of hydrobiid snails determinad by climate and evolutionary history. Freshwater Biology 63: 1225-1239.

https://doi.org/10.1111/fwb.13128

OsIKOWSKI A., HOFMAN S., RYSIEWSKA A., SKET B., PREVORČNIK S., FALNIOWSKi A. 2018. A case of biodiversity overestimation in the Balkan Belgrandiella A. J. Wagner, 1927 (Caenogastropoda: Hydrobiidae): molecular divergence not paralleled by high morphological variation. Journal of Natural History 52: 323-344. https://doi.org/10.1080/00222933.2018.1424959

RADOMAN P. 1973. New classification of fresh and brackish water Prosobranchia from the Balkan and Asia Minor. Posebna Izdanja, Prirodnjacki Musej u Beogradu 32: 1-30.

RADOMAN P. 1983. Hydrobioidea a superfamily of Prosobranchia (Gastropoda). I. Systematics. Serbian
Academy of Sciences and Arts, Monographs 547, Department of Sciences 57: 1-256.

RÉGNIER C., FONTAINE B., BOUCHET P. 2009. Not knowing, not recording, not listing: numerous unnoticed mollusk extinctions. Conservation Biology 23: 1214-1221. https://doi.org/10.1111/j.1523-1739.2009.01245.x

RYSIEWSKA A., PREVORČNIK S., OSIKOWSKI A., HOFMAN S., BERAN L., FALNIOWSKI A. 2017. Phylogenetic relationships in Kerkia and introgression Hauffenia and Kerkia (Caenogastropoda: Hydrobiidae). Journal of Zoological Systematics and Evolutionary Research 55: 106-117. https://doi.org/10.1111/jzs.12159

SCHLICKUM W. R., SCHÜTT H. 1971. Lithoglyphulus, eine neue Prosobranchiergattung. Archiv für Molluskenkunde 101: 289-293.

Strong E. E., GARgominy O., Ponder W. F., Bouchet P. 2008. Global diversity of gastropods (Gastropoda; Mollusca) in freshwater. Hydrobiologia 595: 149-166. https://doi.org/10.1007/s10750-007-9012-6

SZAROWSKA M. 2006. Molecular phylogeny, systematics and morphological character evolution in the Balkan Rissooidea (Ceanogastropoda). Folia Malacologica 14: 99-168. https://doi.org/10.12657/folmal.014.014

THORNES J. B., LÓPEZ-BERMúdez F., WOODWARD J. C. 2009. Hydrology, river regimes and sediment yield. In: WoOdWARD J. C. (ed.). The Physical Geography of the Mediterranean. Oxford University Press, Oxford, pp. 229-253.

https://doi.org/10.1093/oso/9780199268030.003.0020

VUČKOVIĆ N. 2013. Diversity of freshwater molluscs (Gastropoda, Bivalvia) of the Krka National Park. Diploma thesis, Faculty of Science, Department of Biology, University of Zagreb, Croatia.

ŽGANEC K., LAJTNER J., ĆUK R., CRNČAN P., PUŠIĆ I., AtANACKOVIĆ A., Kralj T., VAlić D., Jelić M., MAGUIRE I. 2020. Alien macroinvertebrates in Croatian freshwaters. Aquatic Invasions 15: 593-615. https://doi.org/10.3391/ai.2020.15.4.04

Received: February 1st, 2021

Revised: March 17th, 2021

Accepted: April 11th, 2021

Published on-line: May 10th, 2021 


\section{APPENDIX 1}

\section{LIST OF INVESTIGATED SITES}

The data in the list are as follows: site number, geographical co-ordinates, name of the nearest settlement, site description, date of investigation. For location of the sites see Fig. 1

\section{ZRMANJA RIVER}

$\mathrm{Z} \mathrm{rm} \mathrm{a} \mathrm{n} \mathrm{j} \mathrm{a} \mathrm{I}$

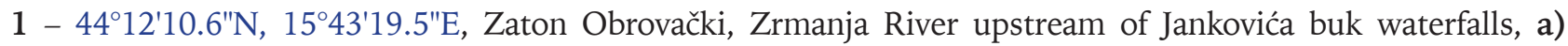
16.8.2013, b) 28.6.2015, c) 11.7.2019, d) 5.7.2020;

$2-44^{\circ} 12^{\prime} 13.8^{\prime \prime} \mathrm{N}, 15^{\circ} 43^{\prime} 30.2^{\prime \prime E}$, Zaton Obrovački, Zrmanja River ca. 400 m upstream of Jankovića buk waterfalls, 28.6.2015;

$3-44^{\circ} 12^{\prime} 23.8^{\prime \prime} \mathrm{N}, 15^{\circ} 43^{\prime} 35.2^{\prime \prime} \mathrm{E}$, Zaton Obrovački, Zrmanja River near ruin of castle St. Obrovac, at destroyed hydro-power station, a) 13.8.2009 (BERAN 2011), b) 30.6.2015;

$4-44^{\circ} 12^{\prime} 21.4^{\prime \prime} \mathrm{N}, 15^{\circ} 43^{\prime} 47.9^{\prime \prime} \mathrm{E}$, Zaton Obrovački, Zrmanja River ca. $200 \mathrm{~m}$ upstream of destroyed hydro-power station, 30.6.2015;

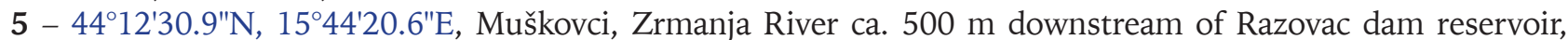
6.7.2017;

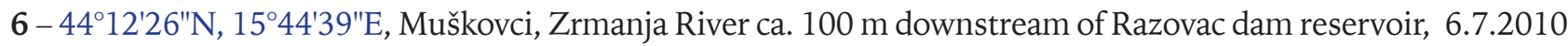
(BERAN 2011);

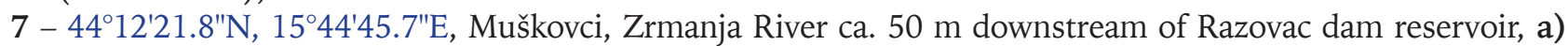
12.7.2018, b) 6.7.2020;

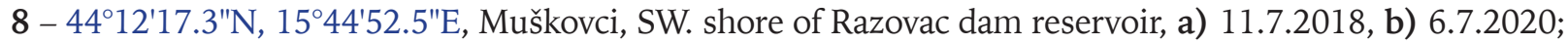

$9-44^{\circ} 12^{\prime} 08.5^{\prime \prime} \mathrm{N}, 15^{\circ} 45^{\prime} 10.1^{\prime} \mathrm{E}$, Muškovci, S. shore of Razovac dam reservoir, 10.7.2018;

$10-44^{\circ} 12^{\prime} 05.6^{\prime \prime} \mathrm{N}, 1^{\circ} 45^{\prime} 29.4^{\prime \prime} \mathrm{E}$, Berberi, left arm of Zrmanja River at its inflow to Razovac dam reservoir, 29.6.2015;

$11-44^{\circ} 12^{\prime} 00.7^{\prime \prime} \mathrm{N}, 15^{\circ} 45^{\prime} 47.4^{\prime \prime} \mathrm{E}$, Berberi, right arm of Zrmanja River at its inflow to Razovac dam reservoir, 29.6.2015;

$\mathrm{Z} \mathrm{r} \mathrm{m} \mathrm{a} \mathrm{n} \mathrm{j} \mathrm{a} \mathrm{I} \mathrm{I}$

$12-44^{\circ} 11^{\prime} 50^{\prime \prime} \mathrm{N}, 15^{\circ} 46^{\prime} 01.1^{\prime \prime E}$, Berberi, Zrmanja River downstream of Berberov buk waterfall, a) 3.7.2014, b) 7.7.2016;

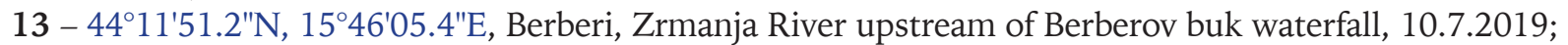

$14-44^{\circ} 11^{\prime} 44.9^{\prime \prime} \mathrm{N}, 15^{\circ} 46^{\prime} 10.8^{\prime \prime} \mathrm{E}$, Berberi, Zrmanja River upstream of bridge near Berberov buk waterfall, a) 9.8.2009 and 14.8.2009 (BERAN 2011), b) 2.8.2012, c) 1.7.2015, d) 3.7.2016, e) 9.7.2018, f) 9.7.2019;

$15-44^{\circ} 11^{\prime} 44.2^{\prime \prime} \mathrm{N}, 15^{\circ} 46^{\prime} 33.9^{\prime \prime} \mathrm{E}$, Berberi, Zrmanja River ca. $400 \mathrm{~m}$ upstream of Berberov buk waterfall, 4.7.2014;

$16-44^{\circ} 11^{\prime} 35.7^{\prime \prime} \mathrm{N}, 15^{\circ} 46^{\prime} 52.5^{\prime \prime}$, Berberi, Zrmanja River ca. $700 \mathrm{~m}$ upstream of Berberov buk waterfall, 1.7.2015;

$17-44^{\circ} 11^{\prime} 35.0^{\prime \prime} \mathrm{N}, 15^{\circ} 47^{\prime} 07.2^{\prime \prime E}$, Dramotiči, Zrmanja River downstream of waterfall, a) 14.8.2013, b) 3.7.2016;

$18-44^{\circ} 11^{\prime} 40.7^{\prime \prime N}, 15^{\circ} 47^{\prime} 22.3^{\prime \prime E}$, Dramotiči, Zrmanja River upstream and downstream of small waterfall, a) 30.7.2012, b) 11.8.2013, c) 9.7.2016, d) 9.7.2019;

$19-44^{\circ} 11^{\prime} 37.7^{\prime \prime N}, 15^{\circ} 47^{\prime} 35.6^{\prime \prime} \mathrm{E}$, Dramotiči, Zrmanja River downstream of waterfall (left bank) at big rock, a) 3.7.2010, 4.7.2010, 6.7.2010 (BERAN 2011), b) 29.6.2014, c) 9.7.2019;

$20-44^{\circ} 11^{\prime} 36.8^{\prime \prime} \mathrm{N}, 15^{\circ} 47^{\prime} 47.4^{\prime \prime} \mathrm{E}$, Dramotiči, Zrmanja River between two waterfalls, a) 5.7.2016, b) 10.7.2019;

$21-44^{\circ} 11^{\prime} 32.6^{\prime \prime} \mathrm{N}, 15^{\circ} 47^{\prime} 56.5^{\prime \prime} \mathrm{E}$, Dramotiči, Zrmanja River ca. 1,300 m downstream of Visoki buk waterfall at small rapids, 11.8.2013;

$22-44^{\circ} 11^{\prime} 28.2^{\prime \prime} \mathrm{N}, 15^{\circ} 48^{\prime} 03.9^{\prime \prime} \mathrm{E}$, Dramotiči, Zrmanja River at small island, 6.7.2016;

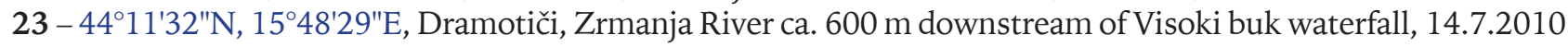
(BERAN 2011);

$24-44^{\circ} 11^{\prime} 29.1^{\prime \prime N}, 15^{\circ} 48^{\prime} 34.1^{\prime \prime E}$, Dramotiči, Zrmanja River ca. 500 m downstream of Visoki buk waterfall, 11.8.2013;

$25-44^{\circ} 11^{\prime} 23.7^{\prime \prime N}, 15^{\circ} 48^{\prime} 43$ "E, Dramotiči, Zrmanja River downstream of Visoki buk waterfall, 14.8.2013;

$26-44^{\circ} 11^{\prime} 16.9^{\prime \prime N}, 15^{\circ} 48^{\prime} 47.7^{\prime \prime} \mathrm{E}$, Dramotiči, Zrmanja River upstream of Visoki buk waterfall, 14.8.2013;

$\mathrm{Z} \mathrm{rm} \mathrm{a} \mathrm{n} \mathrm{j} \mathrm{a} \mathrm{I} \mathrm{I} \mathrm{I}$

$27-44^{\circ} 10^{\prime} 52.9^{\prime \prime N}, 15^{\circ} 49^{\prime} 04.9^{\prime \prime E}$, Golubić, Zrmanja River ca. 750 m upstream of inflow of Krupa River, 2.7.2015; 
$28-44^{\circ} 10^{\prime} 34.7^{\prime \prime} \mathrm{N}, 15^{\circ} 49^{\prime} 15.9^{\prime \prime} \mathrm{E}$, Kaštel Žegarski, Zrmanja River next to big rock ca. $5 \mathrm{~km}$ downstream of bridge in Kaštel Žegarski, 2.7.2015;

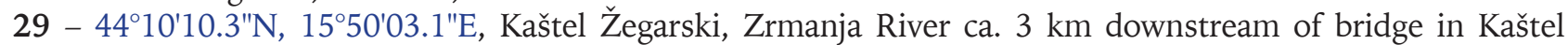
Žegarski, 2.7.2015;

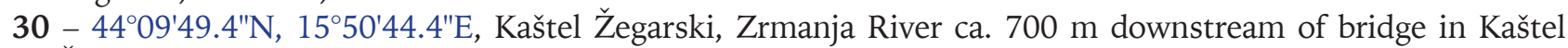
Žegarski, 5.7.2014;

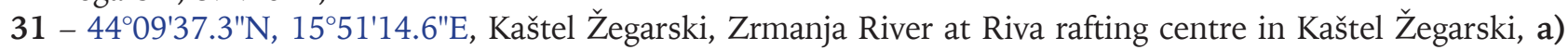
11.7.2019, b) 9.7.2020;

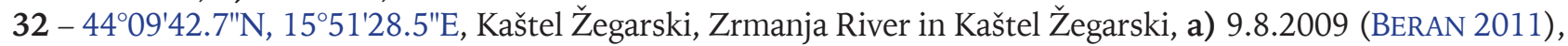
b) 4.7.2010 (BERAN 2011), c) 13.7.2018;

$33-44^{\circ} 09^{\prime} 36.3^{\prime \prime N}, 15^{\circ} 52^{\prime} 11.3^{\prime \prime E}$, Kaštel Žegarski, Zrmanja River at inflow of small tributary ca. $1 \mathrm{~km}$ from bridge in Kaštel Žegarski, 10.7.2017;

$34-44^{\circ} 09^{\prime} 05.3^{\prime \prime} N, 15^{\circ} 53^{\prime} 11.4^{\prime \prime E}$, Prndelji, Zrmanja River upstream of bridge in Prndelji, a) 8.7.2010 (BERAN 2011), b) 10.7.2017;

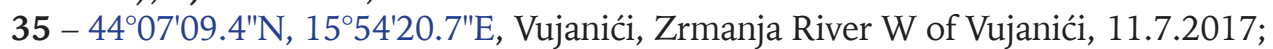

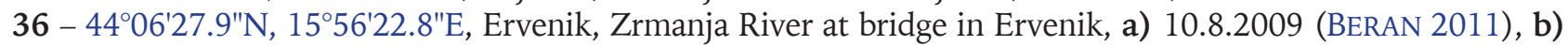
8.7.2010 (BERAN 2011), c) 11.7.2017;

$37-44^{\circ} 05^{\prime} 31.1^{\prime \prime} \mathrm{N}, 16^{\circ} 02^{\prime} 01.0^{\prime \prime} \mathrm{E}$, Mokro Polje, Zrmanja River in Mokro Polje at bridge, a) 10.8.2009 (BERAN 2011), b) 8.7.2010 (BERAN 2011), c) 10.7.2018;

$38-44^{\circ} 05^{\prime} 50.0^{\prime \prime} \mathrm{N}, 16^{\circ} 04^{\prime} 31.2^{\prime \prime} \mathrm{E}$, Prevjes, Zrmanja River at bridge, 1.9.2018;

$39-44^{\circ} 08^{\prime} 18^{\prime \prime N}, 16^{\circ} 04^{\prime} 30$ "E, Palanka, Zrmanja River in Palanka at bridge, 10.8.2010 (BERAN 2011);

$40-44^{\circ} 11^{\prime} 59^{\prime \prime N}, 16^{\circ} 03^{\prime} 49^{\prime \prime E}$, Zrmanja Vrelo, Zrmanja River ca. $2 \mathrm{~km}$ downstream of its soure, 8.7.2010 (BERAN 2011);

$41-44^{\circ} 12^{\prime} 12.5^{\prime \prime} \mathrm{N}, 16^{\circ} 04^{\prime} 21.9^{\prime \prime} \mathrm{E}$, Zrmanja Vrelo, Zrmanja River in Zrmanja Vrelo ca. $1 \mathrm{~km}$ downstream of its source, 8.7.2018;

42 - $44^{\circ} 12^{\prime} 16.7^{\prime \prime} \mathrm{N}, 16^{\circ} 04^{\prime} 49.9^{\prime \prime} \mathrm{E}$, Zrmanja Vrelo, Zrmanja River in Zrmanja Vrelo ca. $400 \mathrm{~m}$ downstream of its source, 8.7.2018;

$\mathrm{Kr}$ u p a $\mathrm{R}$ i v e r

$43-44^{\circ} 11^{\prime} 17.5^{\prime \prime} \mathrm{N}, 15^{\circ} 49^{\prime} 04.6^{\prime \prime}$, Golubić, Krupa River ca. $450 \mathrm{~m}$ upstream of its inflow to Zrmanja River, 2.7.2015;

$44-44^{\circ} 11^{\prime} 14.8^{\prime \prime N}, 15^{\circ} 50^{\prime} 43.1^{\prime \prime E}$, Golubić, Krupa River downstream of waterfalls downstream of Kudin most bridge, 2.7.2014;

$45-44^{\circ} 11^{\prime} 16.5^{\prime \prime} \mathrm{N}, 15^{\circ} 50^{\prime} 48.6^{\prime \prime} \mathrm{E}$, Golubić, Krupa River between Kudin most bridge and waterfalls upstream of bridge, a) 2.7.2014, b) 8.7.2019;

$46-44^{\circ} 11^{\prime} 22.7^{\prime \prime} \mathrm{N}, 15^{\circ} 50^{\prime} 51.1^{\prime} \mathrm{E}$, Golubić, Krupa River upstream of travertine cascades ca. $200 \mathrm{~m}$ upstream of Kudin most bridge, 2.7.2014;

$47-44^{\circ} 11^{\prime} 27.0^{\prime \prime} \mathrm{N}, 15^{\circ} 51^{\prime} 01.5^{\prime \prime E}$, Golubić, Krupa River upstream of inflow of Krnjeza Brook, 8.7.2019;

$48-44^{\circ} 11^{\prime} 23.0^{\prime \prime} \mathrm{N}, 15^{\circ} 51^{\prime} 43.1^{\prime \prime E}$, Krupa, Krupa River upstream of waterfall ca. 1,500 m upstream of inflow of Krnjeza Brook, 10.7.2019;

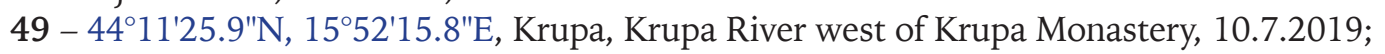

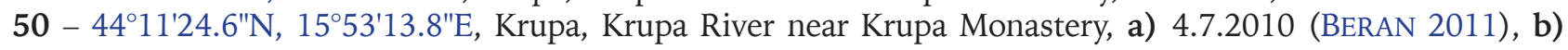
13.7.2018;

$51-44^{\circ} 11^{\prime} 32.8^{\prime \prime} \mathrm{N}, 1^{\circ} 54^{\prime} 33.5^{\prime \prime}$, Krupa, Krupa River in Krupa near bridge, a) 14.7.2010 (BERAN 2011), b) 13.7.2018;

$52-44^{\circ} 11^{\prime} 39.3^{\prime \prime} \mathrm{N}, 15^{\circ} 54^{\prime} 34.5^{\prime \prime} \mathrm{E}$, Krupa, Krupa River and small spring ca. $140 \mathrm{~m}$ upstream of bridge in Krupa, 17.8.2013;

$53-44^{\circ} 11^{\prime} 47.3^{\prime \prime} \mathrm{N}, 15^{\circ} 54^{\prime} 32.3^{\prime \prime E}$, Krupa, source of Krupa River, 17.8.2013;

$\mathrm{S} \mathrm{mall}$ tributaries and $\mathrm{spring} \mathrm{s}$

$54-44^{\circ} 12^{\prime} 39.8^{\prime \prime} \mathrm{N}, 15^{\circ} 44^{\prime} 23.6^{\prime \prime} \mathrm{E}$, Muškovci, small spring NW of Razovac dam reservoir, 6.7.2017;

$55-44^{\circ} 12^{\prime} 05^{\prime \prime} \mathrm{N}, 15^{\circ} 46^{\prime} 02^{\prime} \mathrm{E}$, Muškovci, Dabarnica Brook ca. $200 \mathrm{~m}$ upstream of Razovac dam reservoir, 6.7.2010 (BERAN 2011);

$56-44^{\circ} 12^{\prime} 12.0^{\prime \prime} \mathrm{N}, 15^{\circ} 46^{\prime} 19.2^{\prime \prime} \mathrm{E}$, Muškovci, two small springs by path along Dabarnica Brook, 29.6.2014;

$57-44^{\circ} 12^{\prime} 16.4^{\prime \prime} \mathrm{N}, 15^{\circ} 46^{\prime} 24.7^{\prime \prime} \mathrm{E}$, Muškovci, source of left arm of Dabarnica Brook, 29.6.2014;

$58-44^{\circ} 11^{\prime} 46.3^{\prime \prime} \mathrm{N}, 15^{\circ} 46^{\prime} 00.9^{\prime \prime} \mathrm{E}$, Berberi, small tributary (Džebinovac) ca. $20 \mathrm{~m}$ upstream of its inflow to Zrmanja River, 9.7.2018; 
$59-44^{\circ} 11^{\prime} 27.3^{\prime \prime} \mathrm{N}, 15^{\circ} 45^{\prime} 58.8^{\prime \prime} \mathrm{E}$, Berberi, small spring under rock in small valley south of Berberov buk waterfall, a) 3.7.2014, b) 1.7.2015;

$60-44^{\circ} 11^{\prime} 31.3^{\prime \prime} \mathrm{N}, 15^{\circ} 47^{\prime} 06.1^{\prime \prime} \mathrm{E}$, Dramotiči, spring by Zrmanja River downstream of waterfalls, a) 14.8.2013, b) 29.6.2014;

$61-44^{\circ} 11^{\prime} 16.8^{\prime \prime} \mathrm{N}, 15^{\circ} 49^{\prime} 03.9^{\prime \prime} \mathrm{E}$, Golubić, small spring next to Krupa River ca. $450 \mathrm{~m}$ upstream of its inflow to Zrmanja River, 2.7.2015;

$62-44^{\circ} 11^{\prime 28.7 " N}$, 1551'03.7"E, Golubić, Krnjeza Brook upstream of its inflow to Krupa River, 8.7.2019;

$63-44^{\circ} 11^{\prime} 31.4^{\prime \prime} \mathrm{N}, 15^{\circ} 52^{\prime} 46.9^{\prime \prime E}$, Krupa, spring and rivulet W of Krupa Monastery, 10.7.2019;

$64-44^{\circ} 11^{\prime} 41.6^{\prime \prime} \mathrm{N}, 15^{\circ} 53^{\prime} 53.4^{\prime \prime} \mathrm{E}$, Krupa, tributary (Orovača) of Krupa River W of Krupa, 30.6.2014;

$65-44^{\circ} 11^{\prime} 47.2^{\prime \prime} \mathrm{N}, 15^{\circ} 53^{\prime} 49.4^{\prime \prime E}$, Krupa, source of tributary of Krupa River W of Krupa, 30.6.2014;

$66-44^{\circ} 11^{\prime} 33^{\prime \prime N}, 15^{\circ} 54^{\prime} 34^{\prime \prime E}$, Krupa, spring by Krupa River near bridge, a) 14.7.2010 (BERAN 2011), b) 13.7.2018;

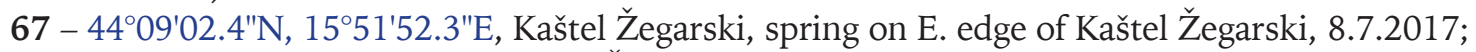

$68-44^{\circ} 09^{\prime} 36.1^{\prime \prime N}, 15^{\circ} 52^{\prime} 11.3 " \mathrm{E}$, Kaštel Žegarski, small canal upstream of its inflow to Zrmanja River, 10.7.2017;

$69-44^{\circ} 09^{\prime} 36.8^{\prime \prime} \mathrm{N}, 15^{\circ} 52^{\prime} 42.5^{\prime \prime E}$, Kaštel Žegarski, rivulet ca. 50 m downstream of spring NE of Kaštel Žegarski, 8.7.2017;

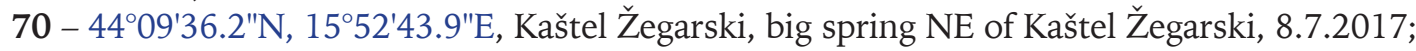

$71-44^{\circ} 11^{\prime} 47.7^{\prime \prime} \mathrm{N}, 16^{\circ} 03^{\prime} 23.1^{\prime \prime E}$, Zrmanja Vrelo, spring near monument in Zrmanja Vrelo, 8.7.2018;

$72-44^{\circ} 11^{\prime} 47.3^{\prime \prime} \mathrm{N}, 16^{\circ} 03^{\prime} 23.5^{\prime \prime} \mathrm{E}$, Zrmanja Vrelo, small tributary near monument in Zrmanja Vrelo, 8.7.2010 (BERAN 2011);

$73-44^{\circ} 12^{\prime} 16.9^{\prime \prime} \mathrm{N}, 16^{\circ} 04^{\prime} 47.5^{\prime \prime} \mathrm{E}$, Zrmanja Vrelo, small spring by Zrmanja River ca. $450 \mathrm{~m}$ downstream of its source, 8.7.2018.

\section{APPENDIX 2}

Table 1. Zrmanja I - list of freshwater molluscs recorded in the lower section of the Zrmanja River. $\mathrm{x}$ - few specimens, $\mathrm{xx}$ - scattered occurrence, xxx - abundant occurrence, $(\mathrm{x})$ - old shells only, $\Sigma$ - number of sites with the occurrence of particular species (number of sites with the occurrence of old shells only in parentheses)

\begin{tabular}{|c|c|c|c|c|c|c|c|c|c|c|c|c|c|c|c|c|c|c|}
\hline \multirow{2}{*}{ Species } & \multicolumn{18}{|c|}{ Site no. } \\
\hline & $1 \mathrm{a}$ & $1 \mathrm{~b}$ & $1 c$ & $1 \mathrm{~d}$ & 2 & $3 a$ & $3 b$ & 4 & 5 & 6 & $7 \mathrm{a}$ & $7 \mathrm{~b}$ & $8 \mathrm{a}$ & $8 \mathrm{~b}$ & 9 & 10 & 11 & $\Sigma$ \\
\hline \multicolumn{19}{|l|}{ Gastropoda } \\
\hline Theodoxus fluviatilis (Linnaeus, 1758) & $\mathrm{xxx}$ & $\mathrm{xxx}$ & $\mathrm{xxx}$ & $\mathrm{xxx}$ & $\mathrm{xxx}$ & $\mathrm{xxx}$ & $\mathrm{xxx}$ & $\mathrm{xxx}$ & $\mathrm{xx}$ & $\mathrm{xx}$ & $\mathrm{xxx}$ & $\mathrm{xx}$ & $\mathrm{x}$ & $\mathrm{xxx}$ & $\mathrm{x}$ & $\mathrm{x}$ & $\mathrm{xxx}$ & 11 \\
\hline Pyrgula annulata (Linnaeus, 1758) & $\mathrm{x}$ & & & & & & & & & & & & & & & $(\mathrm{x})$ & & $1(1)$ \\
\hline Sadleriana fluminensis (Küster, 1852) & & & & $\mathrm{x}$ & & & & & & & & & & & & $(\mathrm{xx})$ & $\mathrm{xxx}$ & $2(1)$ \\
\hline Dalmatinella fluviatilis Radoman, 1973 & $\mathrm{x}$ & & & & & & & & & & & & & & & & & 1 \\
\hline Tanousia zrmanjae (Brusina, 1866) & $(\mathrm{x})$ & $(\mathrm{x})$ & & $(\mathrm{x})$ & & & & $(\mathrm{x})$ & & & & & & & & $(\mathrm{x})$ & & (5) \\
\hline Emmericia patula (Brumati, 1838) & & & & & & & & & & & & & & & & $(\mathrm{x})$ & $\mathrm{xx}$ & $1(1)$ \\
\hline Bithynia tentaculata (Linnaeus, 1758) & $\mathrm{xxx}$ & $\mathrm{xxx}$ & $\mathrm{xxx}$ & $\mathrm{xxx}$ & $\mathrm{xxx}$ & $\mathrm{xxx}$ & $\mathrm{xxx}$ & $\mathrm{xxx}$ & $\mathrm{xx}$ & $\mathrm{xxx}$ & $\mathrm{xx}$ & $\mathrm{xx}$ & $\mathrm{x}$ & $\mathrm{xxx}$ & $\mathrm{xx}$ & $\mathrm{x}$ & $\mathrm{x}$ & 11 \\
\hline Valvata piscinalis (O. F. Müller, 1774) & $\mathrm{xxx}$ & $\mathrm{xx}$ & $\mathrm{x}$ & & & $\mathrm{xx}$ & $\mathrm{x}$ & $\mathrm{x}$ & & $\mathrm{xxx}$ & $\mathrm{xx}$ & $\mathrm{xx}$ & $\mathrm{xx}$ & $\mathrm{xxx}$ & $\mathrm{xx}$ & $\mathrm{x}$ & $\mathrm{x}$ & 9 \\
\hline Acroloxus lacustris (Linnaeus, 1758) & & & $\mathrm{x}$ & & $\mathrm{x}$ & $\mathrm{x}$ & & & & $\mathrm{x}$ & & & & & & & & 4 \\
\hline Stagnicola fuscus (C. Pfeiffer, 1821) & $\mathrm{xx}$ & $\mathrm{xx}$ & $\mathrm{x}$ & & & $\mathrm{xx}$ & & & & & & & & & & $(\mathrm{x})$ & $\mathrm{x}$ & $3(1)$ \\
\hline Radix ampla (Hartmann, 1821) & $\mathrm{x}$ & $\mathrm{xxx}$ & $\mathrm{xx}$ & $\mathrm{xx}$ & $\mathrm{x}$ & & & & $\mathrm{x}$ & & & & & & & $(\mathrm{xx})$ & & $3(1)$ \\
\hline Radix auricularia (Linnaeus, 1758) & $\mathrm{x}$ & & & & & & $\mathrm{x}$ & & $\mathrm{x}$ & & & & & & & $\mathrm{x}$ & & 4 \\
\hline Planorbis carinatus O. F. Müller, 1774 & $\mathrm{xxx}$ & & $\mathrm{xx}$ & & & $\mathrm{xx}$ & $\mathrm{xx}$ & $\mathrm{x}$ & & & & & & & & $(\mathrm{x})$ & & $3(1)$ \\
\hline Hippeutis complanatus (Linnaeus, 1758) & & & & & & $\mathrm{x}$ & $\mathrm{x}$ & & & $\mathrm{x}$ & & & & & & & & 2 \\
\hline Ancylus fluviatilis (O. F. Müller, 1774) & $\mathrm{x}$ & & & & & & & $\mathrm{x}$ & & & & & & & & & & 2 \\
\hline \multicolumn{19}{|l|}{ Bivalvia } \\
\hline Unio elongatulus C. Pfeiffer, 1825 & $\mathrm{xxx}$ & $\mathrm{xxx}$ & $\mathrm{xxx}$ & $\mathrm{xxx}$ & $\mathrm{xxx}$ & $\mathrm{xxx}$ & $\mathrm{xxx}$ & $\mathrm{xxx}$ & $\mathrm{xxx}$ & $\mathrm{xxx}$ & $\mathrm{xx}$ & $\mathrm{xxx}$ & $\mathrm{xx}$ & $\mathrm{xxx}$ & $\mathrm{x}$ & $\mathrm{xx}$ & $\mathrm{x}$ & 11 \\
\hline Anodonta exulcerata Porro, 1838 & $\mathrm{xx}$ & $\mathrm{x}$ & $\mathrm{x}$ & $\mathrm{xx}$ & $\mathrm{x}$ & $\mathrm{x}$ & $\mathrm{x}$ & $\mathrm{x}$ & $\mathrm{x}$ & $\mathrm{xx}$ & & $\mathrm{x}$ & $\mathrm{x}$ & $\mathrm{x}$ & & & & 8 \\
\hline Corbicula fluminea (O. F. Müller, 1774) & & & $\mathrm{x}$ & $\mathrm{xx}$ & & & & & & & & & & & & & & 1 \\
\hline Pisidium amnicum (O. F. Müller, 1774) & $\mathrm{xxx}$ & $\mathrm{x}$ & $\mathrm{xx}$ & $\mathrm{xx}$ & $\mathrm{x}$ & $\mathrm{xx}$ & $\mathrm{xx}$ & $\mathrm{xx}$ & $\mathrm{x}$ & $\mathrm{xx}$ & & $\mathrm{x}$ & & & & $\mathrm{x}$ & $\mathrm{x}$ & 9 \\
\hline Pisidium casertanum Poli, 1791 & & & & & & & $\mathrm{x}$ & $\mathrm{x}$ & & & & & & & & $\mathrm{x}$ & $\mathrm{x}$ & 4 \\
\hline Pisidium nitidum Jenyns, 1832 & $\mathrm{xx}$ & & $\mathrm{x}$ & & & $\mathrm{x}$ & $\mathrm{x}$ & $\mathrm{x}$ & $\mathrm{x}$ & $\mathrm{x}$ & & $\mathrm{x}$ & & & & & $\mathrm{x}$ & 7 \\
\hline Pisidium subtruncatum Malm, 1855 & & & $\mathrm{x}$ & $\mathrm{x}$ & & $\mathrm{x}$ & $\mathrm{xx}$ & $\mathrm{x}$ & $\mathrm{x}$ & $\mathrm{xx}$ & & $\mathrm{x}$ & $\mathrm{x}$ & & & & $\mathrm{x}$ & 8 \\
\hline Number of species & 14 & 8 & 13 & 9 & 7 & 12 & 12 & 11 & 9 & 10 & 4 & 8 & 6 & 5 & 4 & 7 & 11 & \\
\hline
\end{tabular}




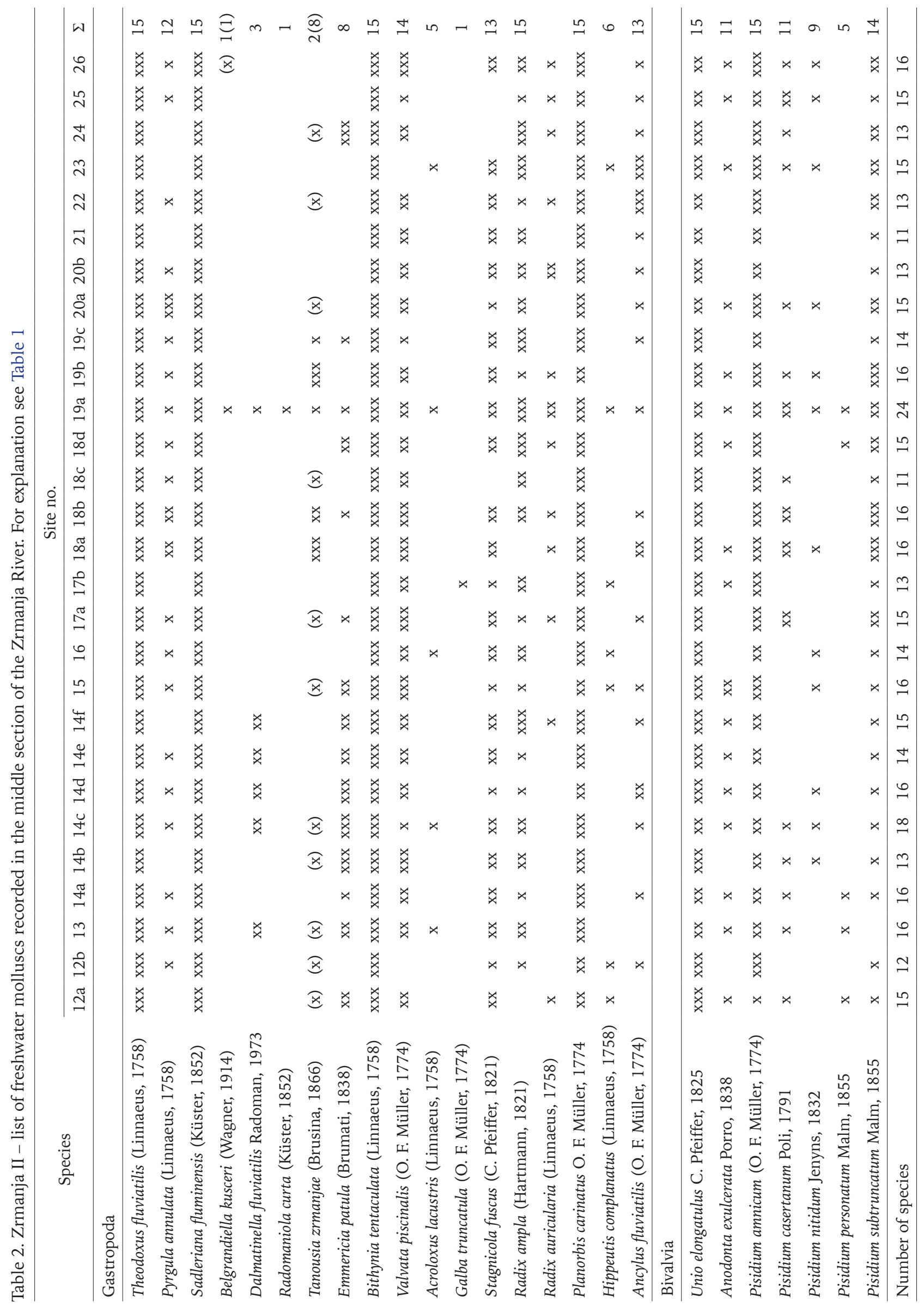




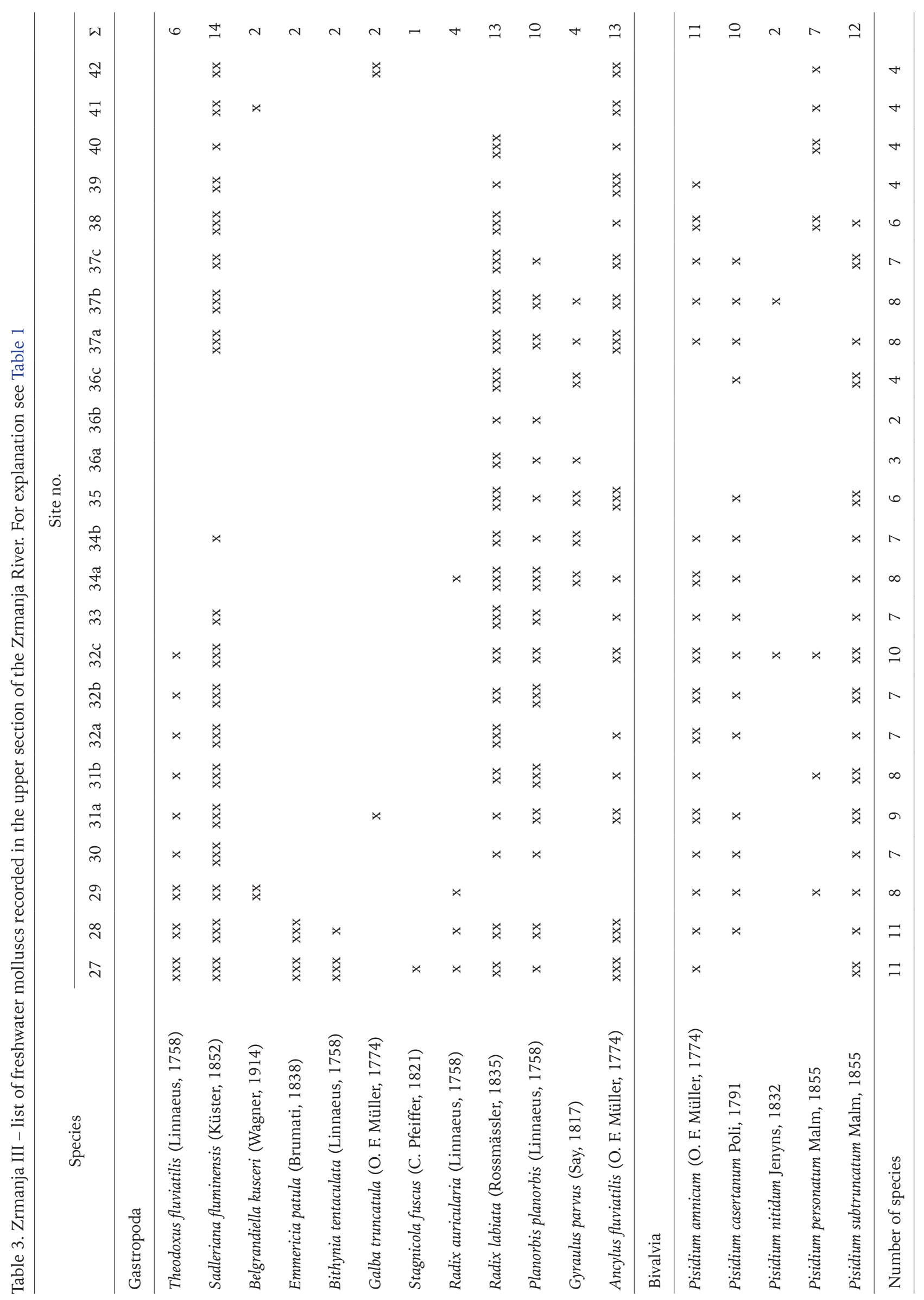


Table 4. Krupa - list of freshwater molluscs recorded in the river. For explanation see Table 1

\begin{tabular}{|c|c|c|c|c|c|c|c|c|c|c|c|c|c|c|c|}
\hline \multirow{2}{*}{ Species } & \multicolumn{15}{|c|}{ Site no. } \\
\hline & 43 & 44 & $45 a$ & $45 b$ & 46 & 47 & 48 & 49 & $50 a$ & $50 \mathrm{~b}$ & $51 \mathrm{a}$ & $51 b$ & 52 & 53 & $\Sigma$ \\
\hline \multicolumn{16}{|l|}{ Gastropoda } \\
\hline Theodoxus fluviatilis (Linnaeus, 1758) & $\mathrm{xxx}$ & $\mathrm{xxx}$ & $\mathrm{xxx}$ & $\mathrm{xxx}$ & $\mathrm{xxx}$ & $\mathrm{xxx}$ & $\mathrm{xxx}$ & $\mathrm{xxx}$ & $\mathrm{xx}$ & $\mathrm{x}$ & & $\mathrm{x}$ & & & 9 \\
\hline Pyrgula annulata (Linnaeus, 1758) & & $\mathrm{xx}$ & & & & & & & & & & & & & 1 \\
\hline Sadleriana fluminensis (Küster, 1852) & $\mathrm{xx}$ & & $(\mathrm{x})$ & & $(\mathrm{xx})$ & $\mathrm{xx}$ & $\mathrm{xx}$ & $\mathrm{x}$ & $\mathrm{xxx}$ & $\mathrm{xxx}$ & $\mathrm{xxx}$ & $\mathrm{xxx}$ & $\mathrm{xxx}$ & & $7(2)$ \\
\hline Belgrandiella kusceri (Wagner, 1914) & & & & & & & & & $\mathrm{x}$ & & $\mathrm{xx}$ & $(\mathrm{x})$ & $\mathrm{xx}$ & $\mathrm{xx}$ & 4 \\
\hline Hadziella sketi Bole, 1961 & & & & & & & & & & & & $(\mathrm{x})$ & $(\mathrm{x})$ & $\mathrm{xxx}$ & $1(2)$ \\
\hline Kerkia sp. Radoman, 1978 & & & & & & & & & & & & & & $(\mathrm{x})$ & (1) \\
\hline Radomaniola curta (Küster, 1852) & & & & & & & & & $\mathrm{xxx}$ & $\mathrm{xx}$ & $\mathrm{xx}$ & $\mathrm{x}$ & $\mathrm{xxx}$ & $\mathrm{xxx}$ & 4 \\
\hline Emmericia patula (Brumati, 1838) & $\mathrm{xxx}$ & $\mathrm{xxx}$ & $\mathrm{xx}$ & $\mathrm{x}$ & $\mathrm{xx}$ & & $\mathrm{x}$ & & $\mathrm{x}$ & $\mathrm{x}$ & & & & & 6 \\
\hline Bithynia tentaculata (Linnaeus, 1758) & $\mathrm{xxx}$ & $\mathrm{xxx}$ & $\mathrm{xxx}$ & $\mathrm{xxx}$ & $\mathrm{xxx}$ & $\mathrm{xxx}$ & $\mathrm{xxx}$ & $\mathrm{xxx}$ & & & & & & & 7 \\
\hline Valvata piscinalis (O. F. Müller, 1774) & & $\mathrm{xx}$ & $\mathrm{x}$ & $\mathrm{x}$ & $\mathrm{xx}$ & $\mathrm{xx}$ & & & & & & & & & 4 \\
\hline Acroloxus lacustris (Linnaeus, 1758) & & $\mathrm{x}$ & $\mathrm{x}$ & & $\mathrm{x}$ & $\mathrm{x}$ & $\mathrm{x}$ & $\mathrm{x}$ & & & & & & & 6 \\
\hline Galba truncatula (O. F. Müller, 1774) & & $\mathrm{x}$ & & & & & & & & & & & $\mathrm{x}$ & & 2 \\
\hline Stagnicola fuscus (C. Pfeiffer, 1821) & $\mathrm{xx}$ & & & & & $\mathrm{x}$ & & & & & & & & & 2 \\
\hline Radix ampla (Hartmann, 1821) & $\mathrm{xx}$ & & & $\mathrm{xx}$ & & $\mathrm{xx}$ & & & & & & & & & 3 \\
\hline Radix auricularia (Linnaeus, 1758) & & & & $\mathrm{x}$ & $\mathrm{x}$ & $\mathrm{xx}$ & $\mathrm{x}$ & & & & & & & & 4 \\
\hline Radix labiata (Rossmässler, 1835) & & & & $\mathrm{x}$ & $\mathrm{xx}$ & $\mathrm{x}$ & $\mathrm{x}$ & $\mathrm{x}$ & & $\mathrm{x}$ & & & & & 6 \\
\hline Planorbis carinatus O. F. Müller, 1774 & $\mathrm{xxx}$ & $\mathrm{xxx}$ & $\mathrm{xxx}$ & $\mathrm{xxx}$ & $\mathrm{xxx}$ & $\mathrm{xxx}$ & $\mathrm{xx}$ & $\mathrm{xx}$ & & & & & & & 7 \\
\hline Hippeutis complanatus (Linnaeus, 1758) & & $\mathrm{x}$ & & & & & & & & & & & & & 1 \\
\hline Ancylus fluviatilis (O. F. Müller, 1774) & & & & & & & $\mathrm{x}$ & $\mathrm{x}$ & $\mathrm{x}$ & $\mathrm{xx}$ & $\mathrm{xxx}$ & & $\mathrm{xx}$ & $\mathrm{xx}$ & 6 \\
\hline \multicolumn{16}{|l|}{ Bivalvia } \\
\hline Unio elongatulus C. Pfeiffer, 1825 & $\mathrm{x}$ & $\mathrm{xxx}$ & $\mathrm{xxx}$ & $\mathrm{xxx}$ & $\mathrm{xxx}$ & $\mathrm{xxx}$ & $\mathrm{xx}$ & $\mathrm{xx}$ & & & & & & & 7 \\
\hline Anodonta exulcerata Porro, 1838 & & $\mathrm{xx}$ & $\mathrm{xx}$ & & $\mathrm{xx}$ & $\mathrm{xx}$ & & & & & & & & & 4 \\
\hline Sphaerium corneum (Linnaeus, 1758) & & $\mathrm{xx}$ & $\mathrm{x}$ & $\mathrm{x}$ & $\mathrm{x}$ & $\mathrm{x}$ & $\mathrm{x}$ & $\mathrm{x}$ & & & & & & & 6 \\
\hline Pisidium amnicum (O. F. Müller, 1774) & $\mathrm{xx}$ & & & & & & & & $\mathrm{x}$ & $\mathrm{x}$ & $\mathrm{xx}$ & $\mathrm{xxx}$ & & & 3 \\
\hline Pisidium casertanum Poli, 1791 & & & & & & & & & $\mathrm{xx}$ & $\mathrm{x}$ & $\mathrm{xx}$ & $\mathrm{x}$ & & & 2 \\
\hline Pisidium nitidum Jenyns, 1832 & & $\mathrm{x}$ & & & $\mathrm{x}$ & & $\mathrm{xx}$ & $\mathrm{x}$ & & & & & & & 4 \\
\hline Pisidium personatum Malm, 1855 & & & & & & & & & $\mathrm{x}$ & $\mathrm{x}$ & & $\mathrm{x}$ & & $\mathrm{x}$ & 3 \\
\hline Pisidium subtruncatum Malm, 1855 & $\mathrm{x}$ & $\mathrm{xx}$ & $\mathrm{x}$ & $\mathrm{x}$ & $x$ & $x$ & & & & $\mathrm{xx}$ & & $\mathrm{x}$ & & & 7 \\
\hline Number of species & 10 & 14 & 10 & 11 & 13 & 14 & 12 & 10 & 9 & 10 & 6 & 7 & 5 & 5 & \\
\hline
\end{tabular}




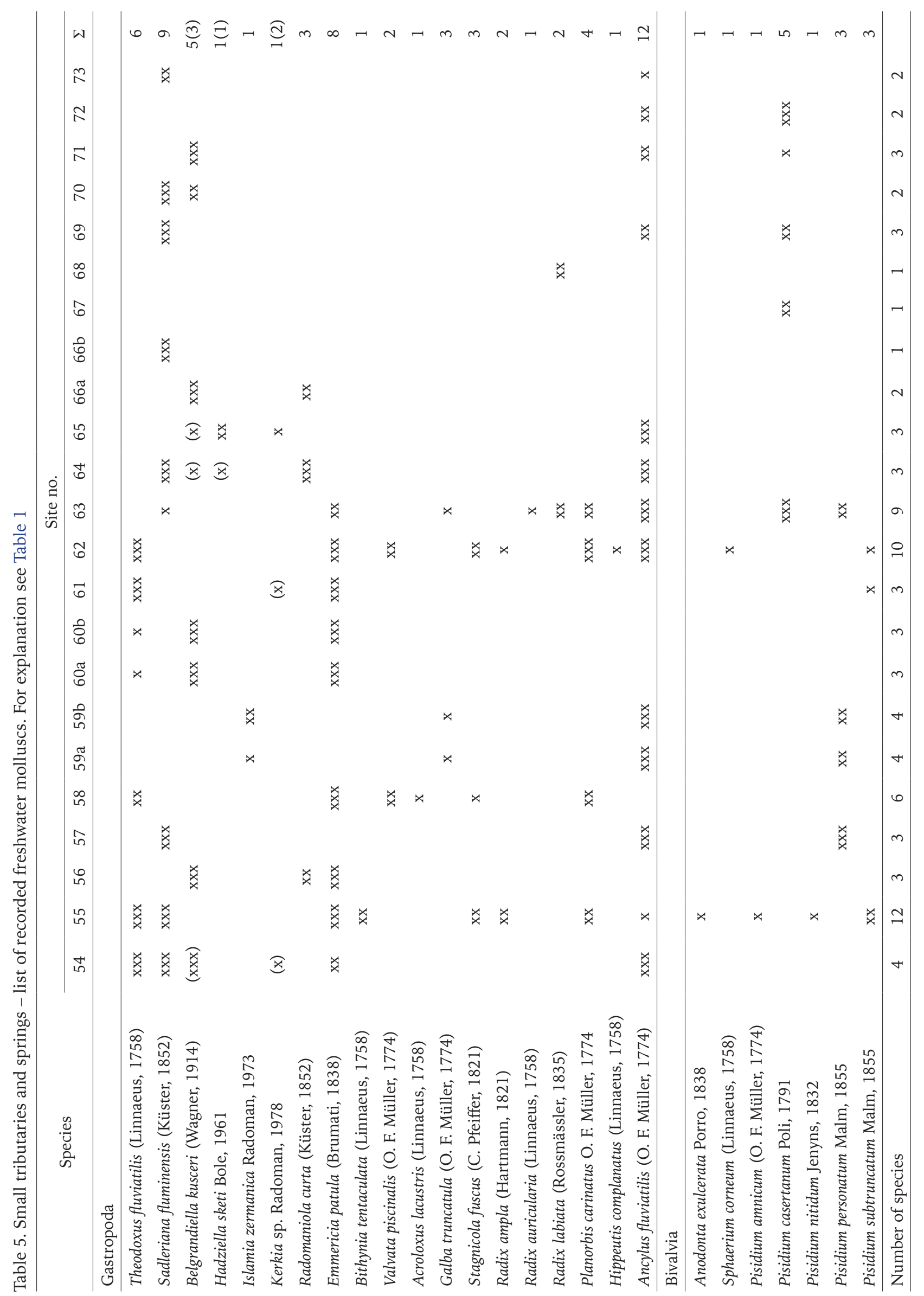

